\title{
Environmental Taxation, Employment and Public Spending in Developing Countries
}

\author{
Karlygash Kuralbayeva ${ }^{1}$
}

Published online: 16 February 2018

(C) The Author(s) 2018. This article is an open access publication

\begin{abstract}
This paper investigates the consequences of environmental tax reforms for unemployment and welfare, in the case of developing countries with a large informal sector, rural-urban migration, and three different assumptions about public spending: (1) as part of a revenue-neutral policy, (2) fixed, and (3) varying endogenously. Under the indexation of unemployment benefits and informal-sector income that give rise to a double dividend, a lower level of public spending is associated with a smaller negative impact on the after-tax income of households and a higher increase in employment. These policies, however, still lead to a reduction in social welfare; even more so in the case of endogenous public spending, although it is associated with a higher increase in employment and a smaller reduction in private-sector incomes. The model implies that complementary policy, in terms of lower public spending, is unlikely to be socially acceptable, and does not support the case for a green tax reforms in developing countries.
\end{abstract}

Keywords Informal sector · Matching frictions · Rural-urban migration · Pollution taxes · Double dividend

A previous version of this paper was circulated under the title, Effects of carbon taxes in an economy with large informal sector and rural-urban migration. I thank Alex Bowen, Emmanuel Combet, Baran Doda, Richard Freeman, and Rick van der Ploeg, as well as seminar participants at LSE, the GRI-GGGI Green Growth conference, and the World Congress of Environmental and Resource Economics (Istanbul) for helpful comments and suggestions. I am also grateful to the editor and the referees for thoughtful comments that have significantly improved the paper. I also thank Anna Grodecka and Eileen Tipoe for excellent research assistance. I was employed by the Grantham Research Institute at LSE for much of the project. I acknowledge financial support by the Global Green Growth Institute (GGGI), the Grantham Foundation for the Protection of the Environment, and the UK Economic and Social Research Council (ESRC) through the Centre for Climate Change Economics and Policy. All potential errors are my own.

Electronic supplementary material The online version of this article (https://doi.org/10.1007/s10640018-0230-3) contains supplementary material, which is available to authorized users.

$\bowtie \quad$ Karlygash Kuralbayeva

k.z.kuralbayeva@1se.ac.uk

1 Department of Geography and Environment, LSE, London, UK 
JEL Classification $\mathrm{H} 20 \cdot \mathrm{H} 23 \cdot \mathrm{H} 30$

\section{Introduction}

Environmental tax reform is one of the most effective tools that can be used in a fundamental transformation towards a green economy. When contemplating the introduction of environmental taxes, governments often consider whether such taxes, besides helping to achieve environmental goals, should also play a larger role in achieving other social and economic targets, such as reduction in unemployment rates. Previous studies, however, found that policies that reduce unemployment rates tend to be costly in terms of other policy objectives as they reduce private incomes, including those of people who are on state benefits. ${ }^{1}$ This makes it politically difficult to implement environmental policies. As a result, to make green tax reforms socially acceptable, economists have argued that complementary policies such as public spending cuts could be used to reduce the environmental tax burden on private sector income (see Koskela and Schob 1999; Bovenberg 1995).

This paper evaluates the implications of this argument for unemployment and social welfare for the case of developing countries. The theoretical framework features an economy with three sectors: urban formal, urban informal, and rural agricultural. Following Pissarides (2000), search and matching frictions form the distinction between formal, or "regulated" jobs, and informal, or "unregulated" jobs. Workers in the informal sector search for jobs in the formal sector, and the unemployment rate is defined as the proportion of the labour force that is in informal-sector self-employment. The economy imports both energy and capital at given world prices to use as inputs in registered production activities.

I consider three public spending policies: (1) as part of a revenue-neutral policy, (2) fixed, and (3) varying endogenously with GDP. As such, I study how various assumptions about public spending impact the effects of environmental policies on unemployment and social welfare. In this way, I am also able to compare the results with previous studies that have focused on revenue-neutral policies. Environmental policies considered in the paper are in the form of increases in energy tax rates. The model is calibrated to match some key aspects of labor markets in Mexico and is solved numerically.

The three main findings of the paper are as follows. First, I find that the income of agricultural workers fall under all policy scenarios, even though they do not pay energy taxes. This is because the higher burden of taxation imposed on the unemployed prompts them to escape the brunt of taxation by searching for a job in the formal sector or by migrating into rural areas. This inflow of labor into the agricultural sector pushes wages down in that sector. This is the key difference to previous studies of the double dividend in the context of developed countries, as it shows the importance of modeling the Harris-Todaro effect (1970) when measuring the incidence of higher energy taxation on poverty within the context of developing countries.

Second, I establish that relative to the scenario of revenue-neutral public policy, environmental tax policies with requirements on public spending, such as (2) and (3), are associated with a larger reduction in the unemployment rate and a lower reduction in after-tax private income. Intuitively, since labor taxes have a broad tax base, when public revenues are fixed there is less scope for the reduction of labor taxes under a revenue-neutral policy compared with when public spending is fixed or if the level of revenues can adjust endogenously. If

1 Bovenberg and van der Ploeg (1998a), Koskela and Schob (1999), Bovenberg (1995), Bovenberg and van der Ploeg (1998b). 
it is also possible to reduce public spending, then the level of required public revenues can decline by more, which creates extra budgetary room for a further reduction in labor taxes, prompting an even larger increase in employment and a lower reduction in formal-sector after-tax income; in fact, the after-tax wage of formal workers increases in this case.

Third, I evaluate the welfare implications of two environmental tax reforms under a taxation scheme that gives rise to a double dividend, ${ }^{2}$ and under the assumption of either fixed or varying public spending. Public spending is assumed to affect households' utility. I find that a given environmental tax policy reduces overall social welfare and the utility of each group of workers in the economy. The equivalent variation of a given energy tax reform is lower when public spending varies endogenously compared to when public spending is fixed, even though the former policy has a smaller negative impact on household incomes.

Finally, sensitivity analysis also reveals that even though a double dividend occurs in the model at the expense of private-sector after-tax income, especially of those who are on state benefits, this result depends critically on the expenditure share of energy when formal sector production is modeled with a standard Cobb-Douglas function and a revenue-neutral green tax reform. Intuitively, with a smaller expenditure share of energy, a decline in energy demand due to higher energy taxes reduces costs, or equivalently results in a smaller tax burden.

These findings thus provide guidance to economists trying to garner support for the implementation of environmental tax policies in developing countries. The model suggests that policymakers in developing countries hoping to improve the labor market effects of environmental policies through lower public spending will likely be unsuccessful, as public services are important determinants of households' well-being in those countries. These results should, however, be seen as highlighting this trade-off when implementing complementary policies aimed at improving the labor market effects of green tax reforms, rather than providing conclusive proof of the incompatibility of green tax reforms with development and poverty alleviation policies in less developed countries. The model abstracts from studying alternative ways of reducing the tax burden on labor (which are beyond the scope of the current paper), which could be potentially more acceptable for economic and political reasons. The results also emphasize the importance of modeling the features relevant for developing countries when assessing consequences of environmental tax reforms in those countries.

More broadly, the results show that the context in which environmental taxation is introduced and the package of complementary reform measures are extremely important, given developing countries' emphasis on the equity and distributional aspects of green policies. Developing countries are the most vulnerable to climate change and resource depletion, and therefore need to embrace policies that help to stimulate economic growth and to promote environmental sustainability, including environmental fiscal reforms. Specific green growth instruments should be identified and used according to the context. This paper contributes to this policy analysis by studying the implications of environmental fiscal reforms, accompanied with reduction in public spending, for job creation and social welfare.

The rest of the paper is organized as follows. Section 2 presents the search and matching model of an economy with an informal sector and rural-urban migration. Section 3 outlines the parameterization of the model. Section 4 discusses results of the policy experiments. Section 5 evaluates the welfare effects of green tax reforms. Section 6 examines the sensitivity of these results to changes in the values of some parameters and functional form. Section 7 concludes.

2 This indexation scheme shifts the tax burden from workers to the unemployed (Bovenberg and van der Ploeg 1998b; Koskela and Schob 1999). An alternative condition under which environmental policy benefits employment is if the tax burden is shifted to capital owners or the owners of resources (see Bovenberg 1995, 1999). 


\section{Model}

This section outlines the theoretical framework in which I conduct the analysis. The model is an extension of the general equilibrium model of Satchi and Temple (2009), with a large informal sector and scope for rural-urban migration, in an economy with a polluting production factor and environmental taxes.

The economy consists of two regions: urban and rural/agricultural, denoted by $m$ and $a$ respectively. The urban sector is characterized by search and matching frictions in the tradition of Pissarides (2000), which partitions the sector into informal/unregistered and formal/registered production activities. Workers allocate themselves between the two sectors via rural-urban migration. Once workers migrate from rural areas, they first enter the informal urban sector.

There are two types of firms: agricultural (rural) sector firms and registered urban-sector firms. Firms operating in rural areas produce goods for consumption in that region only and operate under perfect competition. The economy imports both energy and capital at given world prices, and both are inputs into registered production activities only. ${ }^{3}$ In the informal sector, workers are assumed to be self-employed and engage in low-productivity labor-intensive tasks. Goods from formal and informal production activities are assumed to be perfect substitutes.

Throughout the paper, I use the term "unemployed" to describe people self-employed in the informal sector, and thus treat the fraction of informal sector workers in the urban labor force as the unemployment rate, $u$, so that the size of population normalized to 1 is decomposed into:

$$
L_{a}+(1-u) L_{m}+u L_{m}=1
$$

where $L_{a}$ and $L_{m}$ are the sizes of agricultural and urban sectors, respectively. Consistent with the Harris-Todaro model, all workers are assumed to be risk-neutral. Finally, revenues collected from taxing energy and labor are used to provide general government goods and transfers to the unemployed.

\subsection{Agricultural Sector}

The agricultural sector is modeled as subsistence agriculture, assuming that it does not use energy as an input into production, so capital and labor are the only production factors. As in Satchi and Temple (2009), agricultural capital, $K_{a}$, is interpreted as land. In this sector, each worker produces an output $g\left(k_{a}\right)=\frac{Y_{a}}{L_{a}}$, where $Y_{a}$ is total agricultural production in the economy and $k_{a}$ is the capital to labor ratio, defined as:

$$
k_{a}=\frac{K_{a}}{L_{a}}
$$

The worker is paid a wage $w_{a}$, and derives positive utility from living in a rural area, $\chi_{a}>0 .{ }^{4}$ The agricultural sector is assumed to be perfectly competitive, which implies that:

\footnotetext{
3 This is a simplification; Kuralbayeva (forthcoming) considers the case when the agricultural sector uses energy as a production input to model the presence of pervasive electricity subsidies in the agricultural sector.

4 The labor force is homogeneous in terms of their preferences, so the parameter $\chi_{a}$ is the same for all workers. It is also conceivable that workers derive negative utility from living in a rural area, that is, $\chi_{a}<0$. In that situation, the wage rate in the agricultural sector must be high enough to attract labor from urban areas in order to equate the returns on working in the rural area and working in the urban area informal sector, as will be discussed in Sect. 2.3.
} 


$$
w_{a}=g\left(k_{a}\right)-g_{k}^{\prime}\left(k_{a}\right) k_{a}
$$

where $g_{k}^{\prime}\left(k_{a}\right)=r_{a}$ is the rental cost of capital in the agricultural sector.

\subsection{The Urban Labor Market}

Urban sector goods can be produced from either formal or informal activities. Labor market search-and-matching frictions form the distinction between the production activities of formal goods and informal goods.

\subsubsection{The Labor Market}

In formal labor markets, a constant-returns-to-scale matching function $M_{t}$ determines the number of new matches between job searchers and vacancies:

$$
M_{t}=m\left(s u L_{m}, v L_{m}, M\right)=M\left(s u L_{m}\right)^{\gamma}\left(v L_{m}\right)^{1-\gamma}
$$

where $u L_{m}$ denotes the number of unemployed workers, $s$ is the average search intensity, $v L_{m}$ is the number of open vacancies, and $M$ denotes matching efficiency. Using linear homogeneity of the matching function, it is possible to express contact rates for firms and workers as a function of a single variable $\theta$, defined as:

$$
\theta=\frac{v}{s u}
$$

which measures the labor market tightness. Consequently, the probability of one vacancy being filled is:

$$
q \equiv \frac{M_{t}}{v L_{m}}=M\left(\frac{s u}{v}\right)^{\gamma}=M \theta^{-\gamma}
$$

and $1 / q$ is the expected duration of a vacancy. Note that $q(\theta)$ is a decreasing function of $\theta$, and I define the elasticity of $q$ with respect to $\theta$ as $\varepsilon_{\theta} \equiv-q^{\prime}(\theta) \theta / q>0$. Each match between a worker and firm in the formal sector is assumed to be destroyed by an exogenous Poisson rate $\lambda$, and the law of motion for the number of unemployed satisfies the following condition:

$$
u \dot{L}_{M}=L_{m}(\lambda(1-u)-s u \theta q(\theta))
$$

where $L_{m} \lambda(1-u)$ is the number of separations and $L_{m} s u \theta q(\theta)$ is the number of hires. In the steady state, the inflows and outflows of employment in the informal sector must balance:

$$
\lambda(1-u)=\operatorname{su} \theta q(\theta)
$$

and this determines the relationship between the unemployment rate and the rate of vacancies (labor market tightness) i.e. the Beveridge curve.

\subsubsection{The Worker's Expected Gains}

In the informal sector, each worker receives $z+b-\sigma(s ; z)$, where $z$ denotes the labor productivity (output) of each worker, ${ }^{5} b$ denotes unemployment benefits, and $\sigma(s ; z)$ represents formal job search costs, which depend on search intensity $s$ and labor productivity

\footnotetext{
5 This is a simple specification, which abstracts from modeling how various production factors (energy, capital, and labor) are used in the informal sector production process. Thus I cannot examine the effects of tax policy that operate through the relative energy intensities of the formal sectors and the informal sector. However, those effects could be important in reducing the costs of energy tax reforms through an expansion of the tax base (see Bento Antonio et al. 2012).
} 
$z$. I consider different arrangements concerning the taxation of unemployment benefits and characteristics of the informal labor market by discussing specifications of $b$ and $z$ in Sect. 2.2.5.

I use $U$ and $W$ to denote the value to the worker of being unemployed (and searching for a formal job) and being employed on a formal job, respectively. As the ex-post value of working in formal jobs is the highest, there is an incentive to search for jobs in the formal segment of the urban sector. Informal sector workers decide how actively they search for a formal sector job. A worker $i$, who searches for a job with intensity $s_{i}$, when all other workers search with the same level of intensity $s$, has a matching rate proportional to his relative search intensity $s_{i} / s$ :

$$
\bar{q}_{i}=\frac{s_{i}}{s u L_{m}} m\left(s u L_{m}, v L_{m}\right)=s_{i} q \theta=s_{i} M \theta^{1-\gamma}
$$

Following Satchi and Temple (2009), the optimal level of search intensity for worker $i$ is determined by equating the worker's marginal search costs $\left(\sigma_{s_{i}}\right)$ with the expected benefits $d \bar{q}_{i} / d s_{i}\left(W-U_{i}\right)$ of job search, and then by imposing symmetry:

$$
\sigma_{s}^{\prime}(s ; z)=\theta q(W-U)
$$

while every job searcher finds a job at rate $s q \theta$.

The expected utilities of being unemployed and employed at a formal job can be defined as follows:

$$
\begin{aligned}
& r U=z+b-\sigma+s q \theta(W-U) \\
& r W=w_{m}+\lambda(U-W+P),
\end{aligned}
$$

where $w_{m}$ is the formal-sector wage and $P$ is the severance payment paid by the firm to a departing employee.

\subsubsection{Firms and Labor Demand}

I use $V$ and $J$ to denote the value to the firm of holding a vacancy and a filled job, respectively. I assume that firms pay a flow $\cos t c$ to post a vacancy. Once the vacancy is filled, each firm employs one worker who is paid the wage $w_{m}$, rents capital $k_{m}$ from international capital markets, and imports the polluting production factor energy $e_{m}$ at an exogenously given price $p_{E}$. Firms are liable to energy and payroll taxes. Matches between workers and firms break at an exogenous Poisson rate $\lambda$, at which point the worker returns to the informal sector. The firm makes a severance payment $P$ to the departing employee, which is an important feature of labor markets in developing countries such as Mexico.

Each operating firm with its one employee thus produces the output $A_{m} f\left(k_{m}, e_{m}\right)$, where $A_{m}$ is a TFP parameter and $f\left(k_{m}, e_{m}\right)$ is the intensive form of production technology, with capital $\left(k_{m}\right)$ and energy utilized per worker $\left(e_{m}\right)$, so that:

$$
\begin{aligned}
& r J=A_{m} f\left(k_{m}, e_{m}\right)-\left(1+\tau_{L}\right) w_{m}-r_{m} k_{m}-p_{E}\left(1+\tau_{e, m}\right) e_{m}-\lambda(J+P), \\
& r V=-c+q(J-V),
\end{aligned}
$$

The first-order conditions for the capital-labor ratio and energy-labor ratio are:

$$
A_{m} f_{k}^{\prime}\left(k_{m}, e_{m}\right)=r_{m} ; A_{m} f_{e}^{\prime}\left(k_{m}, e_{m}\right)=p_{E}\left(1+\tau_{e, m}\right)
$$

which imply that:

$$
r J=y\left(k_{m}, e_{m}\right)-\left(1+\tau_{L}\right) w_{m}-\lambda(J+P)
$$


where labor productivity is defined as:

$$
y\left(k_{m}, e_{m}\right) \equiv A_{m} f\left(k_{m}, e_{m}\right)-r_{m} k_{m}-p_{E}\left(1+\tau_{e, m}\right) e_{m} .
$$

Free entry into the creation of vacancies implies $V=0$, that is:

$$
J=\frac{c}{q}
$$

which states that in equilibrium, the expected profit from a job has to cover the expected cost of a vacancy. By combining equations (16) and (17) to eliminate $J$, and assuming that hiring costs are a fixed proportion $v$ of the producer wage in the formal sector, $c=v\left(1+\tau_{L}\right) w_{m}$, I can obtain the following expression:

$$
y\left(k_{m}, e_{m}\right)=\left(1+\tau_{L}\right) w_{m}\left[1+(\lambda+r) \frac{v}{q}\right]+\lambda P
$$

which states that labor productivity equals total labor costs, including wage costs, the expected capitalized value of its hiring costs, and expected severance payments.

\subsubsection{Wage Determination}

Search and matching frictions in the formal urban sector imply that each match gives rise to a surplus that is shared between the firm and its worker through a generalized Nash bargain, which determines wages in formal urban sector according to: ${ }^{6}$

$$
w_{m} \in \arg \max _{w_{m}}(W-U)^{\beta}(J-V)^{1-\beta}
$$

where $\beta$ and $1-\beta$ correspond respectively to the workers' and firms' bargaining strength. The first-order condition for this problem can be written as:

$$
(1-\beta)\left(1+\tau_{L}\right)(W-U)=\beta J
$$

If workers dominate the bargaining process i.e. $\beta \rightarrow 1$, it is clear from equation (20) that their value to the firm, $J$, will be equal to zero and the marginal product of labor equals the costs of labor (including expected severance pay), $\left(1+\tau_{L}\right) w_{m}+\lambda P=y\left(k_{m}, e_{m}\right)$. If, however, the firm holds the entirety of the bargaining power i.e. $\beta=0$, then $W=U$. This simply means that formal sector wages equal workers' reservation wage, $w_{m}+\lambda P=z+b-\sigma$.

Using (11), (12), and (17) to eliminate $W-U$ and $J$ respectively from (20), I can obtain the following expression for the wage rate:

$$
\frac{w_{m}-(z+b-\sigma)}{w_{m}}+\frac{\lambda P}{w_{m}}=\frac{\beta}{1-\beta} v\left(\frac{r+\lambda}{q}+s \theta\right) .
$$

This expression shows that the higher the bargaining power of workers $(\beta)$, the larger is formal sector income (including expected severance pay). A higher interest rate $(r)$, a larger separation rate $(\lambda)$, or a tighter labor market $(\theta)$ raise the rents from a job match and thus raise the wage.

Using (10), (17), and (20), I can rewrite the equation that determines the optimal level of search intensity as:

$$
\sigma_{s}^{\prime}=\frac{\beta}{1-\beta} \theta \nu w_{m}
$$

6 This type of solution, under some conditions, may be justified by application of strategic bargaining theory; see Binmore et al. (1986) and Rogerson et al. (2005). 


\subsubsection{Unemployment Benefits and Informal Sector Labor Productivity}

As discussed in the introduction, one of the conditions for the double dividend in employment to arise is that the tax burden is shifted from workers to recipients of income transfers. This condition critically depends on how green tax reforms affect unemployment benefits (the outside option of employees in the Nash bargaining process) (see Koskela and Schob 1999; Bovenberg and van der Ploeg 1998b). In particular, if unemployment benefits are indexed to consumer prices, then the purchasing power of the unemployed is fixed in real terms. In this situation, the environmental tax reform cannot shift the tax burden from workers to the unemployed, reducing the scope for a double dividend. If, however, the ratio of unemployment compensation to wages is fixed, then the unemployed also share the burden of carbon taxation. By shifting the tax burden away from workers towards the unemployed, employment may expand. $^{7}$

Koskela and Schob (1999) illustrates these insights in a model of wage-bargaining between unions and employers and with environmental taxes on the consumption of 'dirty' goods, while Bovenberg and van der Ploeg (1998b) employ a job search framework and consider environmental taxes in production. The latter also allows for the unemployed to derive (untaxed) income from informal activities. Both papers demonstrate that the potential for double dividend critically depends on the manner in which unemployment benefits are linked to wages and prices. Since the focus of the paper is to analyze how the reduction in public consumption can moderate the costs of green tax reforms on real after-tax private income under conditions that a double dividend arises, the theoretical framework must include elements that cause income in unemployment to be imperfectly linked to the wage level.

As in Bovenberg and van der Ploeg (1998b), I consider environmental taxes in production and model the informal sector, and choose similar indexation schemes for unemployment income, summarized in Cases $\mathrm{A}$ and $\mathrm{C}$ :

Case A Unemployment benefits are fixed at a given level $(b=\bar{b})$. I similarly assume that workers earn a fixed amount of income by engaging in informal activities $(z=\bar{z})$. Since the set up of this model is static and the price of consumption goods is normalized to unity, under this tax regime, the purchasing power of unemployed is fixed in real terms.

Case $C$ Unemployment benefits are assumed to represent some fraction of formal-sector earnings such that $b=\pi_{b} w_{m}$ and $z=\pi_{z}\left(1+\tau_{L}\right) w_{m}$. This indexation rule suggests that labor taxes are evaded in the informal sector, but energy taxes are not. This is a plausible assumption, since pre-existing taxes, such as taxes on labor, tend to be easier to evade than certain forms of environmental taxes, such as carbon taxes or taxes on energy (see e.g., Liu 2013).

In addition, $\mathrm{I}$ introduce case $\mathrm{B}$, an intermediate case between cases $\mathrm{A}$ and $\mathrm{C}$ :

Case B I slightly modify the rule of case C, relaxing the assumption that labor taxes are evaded in the informal sector and assuming that $z=\pi_{z} w_{m}$, while unemployment benefits are linked to wages $\left(b=\pi_{b} w_{m}\right.$, as in Case C). This indexation rule implies that the income of the unemployed moves in line with that of employed workers.

\footnotetext{
7 The importance of this benefit regime for the effects of generic (non-green) tax reform on employment has been also demonstrated, for instance, by Pissarides (1998). He has found that the effects of employment tax cuts are mainly on wages if the ratio of unemployment compensation to wages is fixed, while there are substantial employment effects if unemployment compensation is fixed in real terms.
} 
There are potentially many other indexation schemes (see Koskela and Schob 1999 or Bovenberg and van der Ploeg 1994), with environmental (or other) tax reforms exerting different impacts on income from unemployment. The chosen cases $\mathrm{A}$ and $\mathrm{C}$ represent two extreme and opposing cases when the green tax reform cannot affect unemployment income or can shift the brunt of the tax burden on the unemployed, respectively. These cases are also supported by stylized facts on benefit indexation schemes currently present in some Latin American countries, as discussed in Sect. 2.2.6.

Finally, in contrast to Bovenberg and van der Ploeg (1998b), I simulate the model, which enables me to perform extensive quantitative analysis. Bovenberg and van der Ploeg (1998b) focus on a revenue-neutral tax policy, while I focus on environmental tax policies that do not have to be revenue-neutral but instead allow public revenues and public consumption to change in response to a tax reform. I discuss this further when introducing the government budget constraint in Sect. 2.4.

\subsubsection{Unemployment Insurance Systems in Latin American Countries: A Short Overview}

In this section, I provide a short overview of the unemployment insurance schemes in a selected group of Latin American countries, ${ }^{8}$ which is summarized in Table 1.

In most countries, unemployment benefits are tied to earnings, with minimum and maximum thresholds. For instance, in Chile, benefits are decreasing fraction of renumeration, with $50 \%$ of salary being paid in the first month, $45 \%$ in the second and so on. A similar descending pattern is also in place in Argentina and Uruguay. In Ecuador, the unemployed receive a one-off lump-sum payment upon leaving employment.

Mexico, on the other hand, does not have a nationwide unemployment insurance scheme, but there is still a social security system ${ }^{9}$ in place that allows registered workers to withdraw a maximum of 30 days worth of their pension savings from their individual account once every 5 years, in the event of unemployment. Furthermore, temporary employment programs are in place for workers from rural areas (with benefits being set at $99 \%$ of the local minimum wage), and in order to deal with the weak coverage of the official social security system (less than $50 \%$ of workers), a program named Seguro Popular (SP) was introduced in 2002, providing workers with health but not employment benefits. In addition, Mexico City launched its own unemployment benefit scheme in 2007 (Programa seguro de desempleo del distrito federal). Under this scheme, benefits are restricted to 6 months, and the monthly benefit is worth of 30 days of minimum wage. The existing Mexican programs described above have features that resemble flat-rate systems.

Overall, the stylized facts presented in Table 1 provide evidence for and support the flatrate system and earnings-related indexation scheme of benefits ${ }^{10}$ which characterize the cases outlined in the previous section.

\footnotetext{
8 Some forms of unemployment insurance (UI) currently exist in a handful of developing countries (see Vodopivec 2013; Velasquez 2010; Gerard and Gonzaga 2012), most of them Latin American countries.

9 See: http://www.socialsecurityextension.org/gimi/gess/ShowTheme.do?tid=2667.

10 It is important to note that even though in some countries, unemployment benefits are earnings-related and descending depending on the duration of unemployment, I do not model such unemployment insurance schemes. However, the labor economics literature has hazard rate models that deal with these types of unemployment schemes.
} 
Table 1 Unemployment insurance systems in Latin America

\begin{tabular}{|c|c|}
\hline Country & Unemployment benefits \\
\hline Argentina & $\begin{array}{l}\text { Earnings-related and declining after } 4 \text { months } \\
\text { Non-declining for shorter terms } \\
\text { There are min. and max. values of benefits }\end{array}$ \\
\hline Brazil & $\begin{array}{l}\text { Earnings-related, but within ranges: } \\
\text { Previous income up to } 767.6 \text { BRL: } 80 \% \text { of the average wage } \\
\text { 767,6-1279.46 BRL: } 614.08 \text { BRL+50\% of the excess over } 767 \text { BRL } \\
\text { Previous income above } 1279.46 \text { BRL: } 870.01 \text { BRL } \\
\text { There are min. and max. values of benefits }\end{array}$ \\
\hline Chile & $\begin{array}{l}\text { Earnings-related and descending: } \\
50 \% \text { of the renumeration the first month } \\
45,40,35 \text { and } 30 \% \text { in the following }\end{array}$ \\
\hline Ecuador & $\begin{array}{l}\text { Earnings-related: } \\
\text { Sum set equal to } 3 \text { times the average salary of last } 12 \text { months }\end{array}$ \\
\hline Uruguay & $\begin{array}{l}\text { Earnings-related and descending: } \\
\text { For workers with monthly compensation and jobbers: } \\
50 \% \text { of wage over the last } 6 \text { months, in case of the suspension } \\
\text { In case of a layoff } 66,57,50,45,42 \text { and } 40 \% \text { of the salary } \\
\text { There are min. and max. values of benefits }\end{array}$ \\
\hline Venezuela & $\begin{array}{l}\text { Earnings-related: } \\
60 \% \text { the of average weekly wage of the last } 50 \text { weeks } \\
\text { Min. benefit is } 60 \% \text { of the minimum wage }\end{array}$ \\
\hline Mexico & No nationwide UI, flat-rate systems linked to the minimum wage \\
\hline
\end{tabular}

Sources: Velasquez (2010), Bosch and Campos-Vazquez (2010), Hijzen (2011). The information provided in this table is based on the most recent available data on the latest reforms of unemployment insurance schemes: 1991 in Argentina (http://www.trabajo.gov.ar/segurodesempleo/), 2009 in Chile, 2001 in Ecuador, 2008 in Uruguay, 2005 in Venezuela (http://www.seguridadsocialparatodos.org/aysss/content/sud-america/ venezuela.html), 2007 in Mexico City. Values for Brasil are updated regularly (see, the website of Ministerio do Trabalho e Emprego, MTE, Governo do Brasil). For Mexico see also: http://www.socialsecurityextension. org/gimi/gess/ShowTheme.do?tid=2667.

\subsection{Urban-Rural Migration}

There is scope for migration between urban and rural areas, and once workers migrate from rural areas, they initially enter the informal sector. Migration involves a cost $\phi_{f}|f|$, where $\phi_{f}$ represents the congestion effect caused by migration intensity, ${ }^{11}$ and $f$ represents migration flows from the agricultural sector to the cities (a negative sign would imply a migration flow in the opposite direction). The migration equilibrium condition is defined as follows:

$$
w_{a}+\chi_{a}+r \phi_{f} f=r U
$$

and it states that the discounted value of being employed in the agricultural sector must be equal to the workers' expected utility from entering the informal sector. The steady-state is

11 Migration from rural to urban areas makes it more difficult for workers in the informal sector to find formal-sector jobs, undermining the relative attractiveness of being in the informal urban sector. 
characterized by zero migration flows $(f=0)$ and workers are indifferent between staying in agriculture and the informal urban sector:

$$
w_{a}+\chi_{a}=z+b+\sigma\left[\varepsilon_{\sigma}-1\right]
$$

where $\varepsilon_{\sigma}=s \sigma^{\prime}(s) / \sigma$ is the elasticity of search costs with respect to $s$. The equation states that an increase in unemployment benefits and informal-sector income attracts more labor from the agricultural sector to the informal sector, thus driving up agricultural-sector wages. An increase in search intensity naturally entails a rise in search costs, but also increases the probability of finding a job in the formal sector. Thus, when the expected benefits from search $\left(\sigma \varepsilon_{\sigma}=s \sigma^{\prime}(s)\right)$ exceed the costs $(\sigma(s))$, workers migrate from the agricultural to the informal sector, causing an increase in rural wages.

\subsection{The Government's Budget Constraint}

The government's main commitments are the provision of public goods $G$ and transfers to the unemployed:

$$
G+u L_{m} b=\tau_{L} w_{m}(1-u) L_{m}\left(1+v \frac{r+\lambda}{q}\right)+\tau_{e, m} p_{E} e_{m}(1-u) L_{m}
$$

Goods produced in the formal and informal sectors are assumed to be perfectly substitutable, ${ }^{12}$ and government consumption is restricted to these types of goods. Government revenue includes revenues from taxing energy in the formal sector $\tau_{e, m} p_{E} e_{m}(1-u) L_{m}$, total payroll taxes paid by employees in the formal sector, $\tau_{L} w_{m}(1-u) L_{m}$, and taxes on capitalized recruitment costs, $\tau_{L} w_{m}(1-u) L_{m} v(r+\lambda) / q$.

I examine the effects of green tax policy on labor market outcomes by solving the parametrized model numerically and performing policy experiments along two dimensions. In one dimension, as outlined above, there are the various cases of taxation regimes. In the second dimension, there are different modeling assumptions that can be made about government expenditure, $G$. First, I assume that government expenditure, defined as a fraction of GDP ( $\left.G=\psi Y, Y=Y_{a}+Y_{m}\right)$, varies endogenously. Second, I also consider the case when the level of government expenditure is fixed at its baseline level, i.e. $G=\bar{G}$. Finally, I examine a revenue-neutral policy under which the government budget constraint will be replaced by two equations:

$$
G+u L_{m} b=\Upsilon
$$

and

$$
\Upsilon=\tau_{L} w_{m}(1-u) L_{m}\left(1+v \frac{r+\lambda}{q}\right)+\tau_{e, m} p_{E} e_{m}(1-u) L_{m},
$$

where $\Upsilon$ is total government revenue in the baseline case with energy taxes at $\tau_{e, m}=0.15$.

\section{Parameterization}

Since this model is designed to examine the effects of environmental policies on labor market outcomes, a primary target of the calibration is to produce reasonable figures for labor market characteristics such as the size of the informal sector, agricultural employment, and average

12 This is a common assumption introduced in the literature to model the coexistence of both formal and informal sectors, see Pigott and Whalley (2001), Keen (2008), and Bento Antonio et al. (2012). 
Table 2 Baseline parameter values

\begin{tabular}{lll}
\hline Parameter & Cobb-Douglas pr.f. & CES pr.f. \\
\hline Search model parameters & & \\
$v$ parameter of vacancy posting cost & 0.40 & 0.4 \\
$s$ search intensity & 0.5 & 0.5 \\
$\phi$ search cost elasticity & 2.00 & 2 \\
$\beta$ bargaining strength of workers & 0.5 & 0.5 \\
$M$ matching function efficiency & 0.1 & 0.1 \\
$z_{p}$ indexation of severance pay to wage & 3.36 & 3.36 \\
$\Pi$ search intensity parameter & 3.14 & 3.14 \\
$\gamma$ matching function elasticity & 0.50 & 0.50 \\
$\lambda$ monthly job separation rate & 0.04 & 0.04 \\
Other parameters & & \\
$\tau_{e}$ energy tax rate & 0.15 & 0.15 \\
$r$ monthly interest rate & $0.04 / 12$ & $0.04 / 12$ \\
$r_{m}$ return on capital & $0.04 / 12$ & $0.04 / 12$ \\
$\alpha_{1}$ share of capital in formal sector production & 0.269 & - \\
$\gamma_{1}$ share of capital in agricultural sector & 0.63 & 0.63 \\
$\alpha_{2}$ share of labor in formal sector production & 0.5 & - \\
$\alpha$ share of labor in formal sector production & - & 0.3 \\
$\gamma_{2}$ share parameter in the nested CES function & - & 0.1 \\
$\varepsilon$ elasticity of substitution btw capital/labor \& energy & - & 0.05 \\
$A_{a}$ productivity in agricultural sector & 1 & 1 \\
$A_{m}$ productivity in urban sector & 2 & 5.2 \\
$A^{E}$ fossil energy-augmenting technology & - & 5.2 \\
\hline
\end{tabular}

employment duration. ${ }^{13}$ I calibrate the parameter values using the latest available official data and values similar to existing studies that analyze labor market policies in Mexico (or Latin American countries which share many similar labor characteristics with Mexico). The baseline parameter values are summarized in Tables 2 and 3 reports the characteristics of the labor market implied by the theoretical model as well as the corresponding values from Mexican data. The time period is assumed to be one month.

\subsection{Matching and Labor Market Parameters}

The matching technology is Cobb-Douglas and satisfies $m(s v, u)=M(s u)^{\gamma} v^{1-\gamma}$. I set the value of $\gamma$ equal to 0.5 , which is commonly accepted value in the literature. ${ }^{14}$ I set the values of $M$ and $s$ at 0.1 and 0.5 respectively in order to yield a plausible value for the duration of employment (see Table 3 ). I assume $\beta$ to be equal to 0.5 , as it is again accepted by most of the literature. ${ }^{15}$ The value of parameter $v$ in the vacancy posting cost $\left(c=v\left(1+\tau_{L}\right) w_{m}\right)$ is set

\footnotetext{
13 This section draws heavily on a corresponding one in Kuralbayeva (forthcomig).

14 See Pissarides (1998), Satchi and Temple (2009), and Zenou (2008).

15 See, e.g., Mortensen and Pissarides (1994), Zenou (2008), Albrecht et al. (2009), and Pissarides (1998).
} 
Table 3 Labor market characteristics: data versus model

\begin{tabular}{|c|c|c|c|}
\hline Labor market characteristics & Model & Data & Source \\
\hline Agricultural employment share, $L_{a}$ & 0.13 & 0.13 & $\begin{array}{l}\text { Mexico 2010, World Bank } \\
\text { (SL.AGR.EMPL.ZS) }\end{array}$ \\
\hline Unemployment (informal sector share), $u$ & $30.63 \%$ & $34.1 \%$ & Mexico 2009, LABORSTA, ILO \\
\hline Formal sector wage/rural wage, $w_{m} / w_{a}$ & 2.09 & 1.93 & $\begin{array}{l}\text { Mexico (LABORSTA, ILO) } \\
\text { average } 1995-2008^{a}\end{array}$ \\
\hline Payroll tax rate, $\tau_{L}$ & 0.25 & $0.19,0.27$ & Mexico (2013) OECD \\
\hline Average employment duration & $18.11 \mathrm{mths}$ & $12-27$ mths $^{b}$ & $\begin{array}{l}\text { Mexico }(1992,1993) \\
\text { Gong and van Soest (2002) }\end{array}$ \\
\hline
\end{tabular}

a The number is calculated as the ratio of the monthly wage in the manufacturing sector and that paid in the agricultural sector for all men and women. The respective ratio for Brazil in years 1994-2002 was 2.3, in Peru in years 1989-1993 1.73, in Venezuela 1.40 in year 1997. Satchi and Temple (2009) use the number 1.80 based on ILO data for 1990. Given that data for Mexico is most recent, I target the ratio 1.93 in my calibration.

${ }^{\mathrm{b}}$ Respectively for men women and men

at 0.4. ${ }^{16}$ Following Satchi and Temple (2009), I assume that the average severance payment $P$ is four times the wage, which along with the assumption that $P=z_{P}\left(1+\tau_{L}\right) w_{m}$, yields a value of $z_{p}=3.36$.

I assume the annual interest rates $r$ and $r_{m}$ to be equal to 4\%, which is the value used in the literature (Satchi and Temple 2009; Albrecht et al. 2009). The monthly job separation rate, $\lambda$, is chosen to be at 0.04, as in Gerard and Gonzaga (2012), who base their estimate on monthly data for Brazil. In comparison, Satchi and Temple (2009), using quarterly estimates from Gong and van Soest (2002), calibrate $\lambda$ at 0.06. I decide to set $\lambda$ to 0.04 , which allows me to match the labor data statistics of Mexico better. The parameterization yields an "unemployment" rate (the size of the informal sector as a share of non-agricultural employment) of $30.63 \%$. This number is very close to the official estimate of $34.1 \%$ for Mexico (2009 Q2). ${ }^{17}$

\subsection{Search Intensity, Labor Income and Government}

Following Satchi and Temple (2009), the cost of search intensity function is defined as follows:

$$
\sigma(s)=\Pi z s^{\phi} .
$$

I set the value of $\phi$ at 2 (as in Satchi and Temple 2009), and choose the value of parameter $\Pi$ to generate plausible values for both informal-sector productivity and the total income of the unemployed. The agricultural employment share, $L_{a}$, is chosen to be equal to $0.13,{ }^{18}$ which matches the annual data for Mexico in 2010. The value of $\chi_{a}$ is then inferred from the model's migration equation (24).

\footnotetext{
16 For comparison, Satchi and Temple (2009) set the ratio $c / w_{m}$ equal to 0.4 .

17 This share also includes those who have a formal job. Formal employment in the informal sector, however, only represents a very small fraction of non-agricultural employment. For illustration, I also compute informalsector employment as a share of non-agricultural employment, using data (ILO 2012) on the number of people in informal employment and the number of people in informal employment outside the informal sector. The estimate is $33.5 \%$.

18 Please note that given this parameterization, the agricultural sector is a proxy for the rural area and thus in the paper, the terms agricultural sector and rural area will be used interchangeably.
} 
I assume the payroll tax rate $\tau_{L}$ to be equal to 0.25 , since 2013 OECD data on the average labor income tax (tax wedge) faced by Mexican workers suggests $19.0 \%$ and an average compulsory payment wedge of $26.9 \% .{ }^{19}$ At the same time, payroll taxes may make up a maximum 35\% of the payroll in Mexico (see Handbook 2012). The values for the payroll tax rate used in the literature differ considerably_for instance Satchi and Temple (2009) use a value of 0.1, whilst Albrecht et al. (2009) use a value of 0.5. Since there is no consensus in the literature, I have chosen a payroll tax rate that is in line with recent data on Mexico. I assume the baseline energy tax, $\tau_{e, m}$, to be equal to 0.15 , which together with other parameters allow me to match the share of public consumption in GDP quite well. Specifically, I assume that government spending accounts for $10 \%$ of GDP (i.e., $\psi=0.1$ ), which is consistent with the empirical evidence for Mexico. The average share of general government final consumption expenditure in GDP from 2004-2008 is $10 \%$, which is similar to the $11.4 \%$ share over the past few decades (1991-2013). ${ }^{20}$

\subsection{Production Functions}

The baseline production technologies in the formal and agricultural sectors are Cobb-Douglas and satisfy:

$$
Y_{m}=A_{m} K_{m}^{\alpha_{1}} E_{m}^{1-\alpha_{1}-\alpha_{2}}\left((1-u) L_{m}\right)^{\alpha_{2}} ; \quad Y_{a}=A_{a} K_{a}^{\gamma_{1}} L_{a}^{1-\gamma_{1}} ;
$$

which in intensive forms are respectively defined as follows:

$$
A_{m} f\left(k_{m}, e_{m}\right)=A_{m} k_{m}^{\alpha_{1}} e_{m}^{1-\alpha_{1}-\alpha_{2}} ; \quad g\left(k_{a}\right)=A_{a} k_{a}^{\gamma_{1}}
$$

Cobb-Douglas technology has been used widely (e.g. in Golosov et al. (2014), Barrage (2012), and references therein), and, as argued by Hassler et al. (2012), seems to be a reasonable representation of energy input use for a longer time horizon. I focus on the case of an open capital account for developing countries, assuming that the economy is open to international capital flows so that the return to capital is equal to the world interest rate. In addition, given that the price of energy is determined internationally by world markets, equations (15) imply that both $k_{m}$ and $e_{m}$ are exogenously given. This version of the model can be seen as capturing long-run adjustment, and thus the Cobb-Douglas specification is consistent with this assumption.

I test the sensitivity of the results to a CES production function specification, which is considered to be a better representation of energy demand in the short-and-medium term than a Cobb-Douglas production function (see, e.g. Hassler et al. 2012), assuming instead that formal sector production is given by:

$$
Y_{t}=\left[\left(1-\gamma_{2}\right)\left[A_{t} K_{t}^{\alpha}\left((1-u) L_{t}\right)^{1-\alpha}\right]^{\frac{\varepsilon-1}{\varepsilon}}+\gamma_{2}\left[A_{t}^{E} E_{t}\right]^{\frac{\varepsilon-1}{\varepsilon}}\right]^{\frac{\varepsilon}{\varepsilon-1}}
$$

where $L$ is labor, $A_{t}$ the capital/labor-augmenting technology (later called $A_{m}$ ), $A^{E}$ the fossil-energy-augmenting technology, $\epsilon$ the elasticity of substitution between capital/labor and fossil energy, and $\gamma_{2}$ is a share parameter.

For the baseline Cobb-Douglas technology specification (29), I set the values of the parameters as $\alpha_{1}=0.269, \alpha_{2}=0.5$, and $\gamma_{1}=0.63$ (as in Satchi and Temple 2009). For

\footnotetext{
19 See http://www.oecd.org/ctp/tax-policy/taxingwages-mexico.htm. The average compulsory payment wedge measures the payroll taxes and non-tax compulsory payments.

20 General government final consumption expenditure (\% of GDP) (NE.CON.GOVT.ZS) from the World Bank World Development Indicators includes all government current expenditures for purchases of goods and services (including compensation of employees). It also includes most expenditures on national defense and security, but excludes government military expenditures that are part of government capital formation.
} 
the nested CES production function (31), I set the values of the parameters of the production function as $\alpha=0.3, \varepsilon=0.05,{ }^{21}$ and $\gamma_{2}=0.1 .^{22}$ The values of the exogenous price of energy and augmenting technology are chosen to match the labor data statistics, so that the baseline values for both production function specifications are the same.

These shares give a baseline share of energy costs in total production of $23.1 \%$. For comparison, a value of $40.7 \%$ is an estimate based on a Cobb-Douglas specification used in an analysis of the energy-saving effects of technological progress in Chinese industry, which is characterized by high energy intensity (see Yuan et al. 2009). The estimates of 35 and $17 \%$ are the values of energy input per unit of value added in non-metallic mineral products and paper products respectively across developing countries (see Upadhyaya 2010). Much lower values for the expenditure share of energy have also been used in recent macroeconomic models of climate change (see Golosov et al. 2014 or Barrage 2012) of $1-\alpha_{1}-\alpha_{2}=0.03$. Since, the focus of this analysis is on developing countries, I start with a higher energy intensity of production than used in those studies and perform sensitivity analyses using other values of $1-\alpha_{1}-\alpha_{2}$. I demonstrate that the key results of the paper remain robust to changes in the values of energy intensity.

As $K_{a}$ represents a fixed factor in agricultural production, I can normalize its value to one without loss of generality. Thus, given the knowledge of $L_{a}$, this pins down the value of land per worker in the rural sector, $k_{a}=1 / L_{a}$. In choosing the values of productivity parameters $A_{m}$ and $A_{a}$, I draw on a recent study by Gollin et al. (2014), who demonstrate that by adjusting for different factors such as human capital per worker, the productivity gap between agricultural and non-agricultural sectors in developing countries, measured as value added per worker, could be estimated at around 2 . Accordingly, by normalizing the agricultural-sector productivity to one, $A_{a}=1$, I set the value of $A_{m}$ at 2 .

\subsection{Other Parameters}

I have verified that the conditions of the model (1) $w_{m}+\lambda P>z+b-\sigma$ and (2) $P<w_{m} / \lambda$ hold under this parametrization. The first condition states that workers will only engage in job search if it is worthwhile, that is, the expected return from a formal job is greater than the return from being in the informal sector and searching for a formal job. The second condition implies that the (expected) severance payment $P$ accounts for less than half of expected labor income from employment.

To perform welfare analysis, the households's utility function is defined as follows:

$$
\mathcal{U}(I)=c_{A}^{\alpha_{A}} c_{M}^{\alpha_{M}} G^{\vartheta}
$$

where $\alpha_{A}+\alpha_{M}=1$. I assume $\vartheta=0.1$, which is below the values of 0.4 and 0.2 considered in Ganelli and Tervala (2007) and Sims and Wolff (2014) respectively. ${ }^{23}$ I set the value of $\alpha_{A}$ at 0.3 .

21 The value of the elasticity $\varepsilon=0.05$ (or below), as shown by Hassler et al. (2012), implies the sensible energy-saving and capital-labor saving technology series. Their estimates also suggest that these technology trends are positive and of very similar magnitude, so I therefore set $A=A^{E}$.

22 Empirical estimates of the share of energy in production $\left(\gamma_{2}\right)$ vary by industry. For example, Dissou et al. (2012) find that the value of $\gamma_{2}$ varies between 0.024 (transportation equipment) and 0.186 (primary metals). I set the value of $\gamma_{2}$ in the range of these estimates, close to estimates of the energy share in non-metal mineral products or chemicals.

${ }^{23}$ In Sect. 5 below I discuss how a higher value of $\vartheta$ affects the baseline results. 


\section{Discussion of the Results}

\subsection{Policy Experiments}

For clarity, I again briefly outline the experiment specifications I conduct in the paper, which have been explained in the previous sections. First, I examine the effects of green tax reforms when the total income of the unemployed is fixed in real terms (Case A: $b=\bar{b}, z=\bar{z}$ ). Second, I assume that the income of the unemployed is a fixed proportion of after-tax wages (Case B: $\left.b=\pi_{b} w_{m}, z=\pi_{z} w_{m}\right)$. Third, I study the case where the income of the unemployed is fixed, but labor taxes are evaded in the informal sector (Case C: $b=\pi_{b} w_{m}, z=\pi_{z}\left(1+\tau_{L}\right) w_{m}$ ).

Cases $\mathrm{A}$ and $\mathrm{B}$ are analyzed under the assumption that the provision of public goods is constant $(G=\bar{G})$. Case $\mathrm{C}$ is considered under three assumptions about public expenditure: (1) fixed public spending $(G=\bar{G})$, (2) flexible (endogenous) public spending ( $G=\psi Y, Y=$ $Y_{a}+Y_{m}$ ), and (3) a revenue-neutral tax reform. Case $\mathrm{C}$ is the type of unemployment indexation rule under which the environmental tax policy can affect the income of the unemployed and can shift the tax burden from the workers to unemployed, so the double dividend can arise. By making different assumptions about public spending, I see how changes in public consumption impact private-sector employment and after-tax income.

\subsection{Green Tax Policies: All Policy Scenarios}

In this section, I distill the results and key insights from all five policy experiments outlined in this paper. I study the effects of an environmental tax policy that doubles the value of the energy tax from its baseline value of $\tau_{e, m}=0.15$ to $\tau_{e, m}=0.3$. An increase in energy taxes affects the economy through two channels. First, it decreases energy demand, which in turn decreases the energy tax base. Second, lower energy demand reduces labor productivity and thus labor demand. If the government needs to maintain overall tax revenues, the erosion of the energy tax base prevents the government from reducing labor taxes sufficiently to offset these adverse effects of higher energy taxes on labor productivity, as green taxes have a narrower tax base than labor taxes. Since a reduction in payroll taxes does not fully offset the adverse effects of the pollution tax, the overall tax burden on labor tends to rise. The higher average tax burden on labor generally reduces private-sector after-tax income and raises the labor costs (per unit of output) for firms, and thus tends to reduce labor demand and employment. By lowering the tax burden on labor, or as discussed in this paper, by shifting the tax burden on the unemployed, it is possible to raise employment. However, such an outcome depends on the indexation scheme of income in unemployment, and the extent to which the after-tax income of all labor is reduced by the type of government expenditure policy, which I discuss below.

Table 4 summarizes the effects of an increase in energy taxes on key labor market characteristics, under different policy scenarios. Labor market characteristics include the unemployment rate $(u)$, after-tax real income of the private sector (formal sector wage, $w_{m}$ ), income of the unemployed $(b+z)$, rural sector wages $\left(w_{a}\right)$, search efforts $(s)$, and labor market tightness $(\theta)$. From this table we see that, for instance, the first green tax policy is associated with an increase in the unemployment rate of 0.75 percentage points, a $1.63 \%$ decline in after-tax wages, a $3.83 \%$ decrease in agricultural wages, and a decline in both search efforts and labor market tightness, while unemployment income is unaffected.

The table first demonstrates that a double dividend (a decline in the unemployment rate) occurs when the additional tax burden associated with higher carbon taxation is shifted on to the unemployed, as in the last three experiments. In the first policy experiment, the 
Table 4 Labor market effects of green tax reform under different tax regimes and assumptions about government expenditure: a summary

\begin{tabular}{|c|c|c|c|c|c|c|c|c|}
\hline$G$ & Case & $u$ & $w_{m}(\%)$ & $(b+z)$ & $b$ & $z$ & $w_{a}(\%)$ & $s \quad \theta$ \\
\hline 1. $G=\bar{G}$ & $\begin{array}{l}\mathrm{A}: b=\bar{b} \\
\mathrm{~A}: z=\bar{z}\end{array}$ & 0.75 & -1.63 & 0 & 0 & 0 & -3.83 & $\downarrow \downarrow$ \\
\hline 2. $G=\bar{G}$ & $\begin{array}{l}\text { B: } b=\pi_{b} w_{m} \\
\text { A: } z=\tilde{\pi}_{z} w_{m}\end{array}$ & 0.28 & -1.33 & -1.33 & -1.33 & -1.33 & -3.53 & $\downarrow \downarrow$ \\
\hline 3. Revenue-neutral & $\begin{array}{l}\mathrm{C}: b=\pi_{b} w_{m} \\
\mathrm{~A}: z=\pi_{z}\left(1+\tau_{L}\right) w_{m}\end{array}$ & -0.78 & -1.17 & -4.58 & -1.17 & -5.46 & -3.43 & $\uparrow \downarrow$ \\
\hline 4. $G=\bar{G}$ & $\begin{array}{l}\mathrm{C}: b=\pi_{b} w_{m} \\
\mathrm{~A}: z=\pi_{z}\left(1+\tau_{L}\right) w_{m}\end{array}$ & -0.86 & -0.72 & -4.48 & -0.72 & -5.45 & -2.77 & $\uparrow \downarrow$ \\
\hline 5. $G$ varies & $\begin{array}{l}\mathrm{C}: b=\pi_{b} w_{m} \\
\mathrm{~A}: z=\pi_{z}\left(1+\tau_{L}\right) w_{m}\end{array}$ & -1.06 & 0.46 & -4.23 & 0.46 & -5.44 & -1.02 & $\uparrow \downarrow$ \\
\hline
\end{tabular}

Green tax reform constitutes an increase in the energy tax rate from $\tau_{e, m}=0.15$ (baseline) to $\tau_{e, m}=0.3$; the steady-state value of unemployment is already in percentage terms, so $u=0.75$ (under first policy experiment) means that unemployment increased by 0.75 percentage points, from $30.63 \%$ (baseline) to $31.38 \%$; changes in other variables relative to their baseline values

income of the unemployed remains unaffected by green tax policy. In turn, the tax burden of environmental protection is borne by workers in the remaining sectors of the economy (urban formal and agricultural), in terms of lower urban-sector employment and lower formal- and agricultural-sector income. Intuitively, as the outside option available to workers remains unaffected by green tax policy, this policy effectively raises the bargaining power of workers. Workers thus resist large cuts in after-tax wages, increasing labor costs and reducing formalsector employment. A decrease in formal-sector employment is partially absorbed by the agricultural sector; the inflow of labor into rural areas pushes down agricultural-sector wages.

Under the second policy experiment, with indexation to after-tax wages, the environmental tax policy decreases the income of the unemployed, enabling the government to reduce taxes on labor by more than under the previous scenario, moderating the rise in labor costs and the reduction in employment. As the unemployed now bear some of the costs of a cleaner environment, the adjustment to the additional tax burden triggers a smaller decline in employment and in incomes of workers in both the formal and agricultural sectors compared to the first experiment. Both formal sector wages and the total income of the unemployed fall by the same amount (1.33\%) when carbon taxes are increased from 15 to $30 \%$. This reduction still proves to be insufficient for a double dividend to occur. Instead, green tax reforms only result in a lower unemployment rate when the additional tax burden due to higher energy taxes is shifted more on to the unemployed (the last three policy experiments).

The double dividend from the third policy experiment, which was not present in the second scenario, is due to the assumption in the former case that payroll taxes do not affect informalsector income from self-employment. Under that assumption, a shift from labor taxes towards carbon taxes has a heavier impact on the income of the unemployed from informal activities. Since $z$ represents $93 \%$ of the total income of the unemployed in the baseline case with $\tau_{e, m}=0.15$, the environmental tax policy that replaces an explicit tax on labor with an implicit tax on labor (energy tax) results in a bigger fall in the income of the unemployed than under previous policy experiments, with their income falling by $4.58 \%$ compared with $1.33 \%$ under the previous policy experiment. A larger decline in the outside option weakens 
workers' bargaining power, which prompts them to accept lower wages. This boosts labor demand and reduces unemployment.

Finally, a comparison of the results across the third, fourth, and fifth policy experiments reveals that under the same tax regime, by varying the level of public revenues and government consumption, the impact of a green tax reform on labor markets can be improved: after-tax income in the private sector is highest under the last experiment. To explain the differences in these outcomes, I first note that when $\tau_{e, m}=0.3$, the level of government revenues is $0.7386,0.7307$, and 0.7099 , while the level of public spending is $0.6618,0.6581$, and 0.6321 for the third, fourth, and fifth policies respectively. Since labor taxes have a broad tax base, when government revenues are fixed there is less scope for reducing labor taxes under a revenue-neutral policy, compared to when public spending is fixed but the level of revenues can change. If, in addition, public spending can also be reduced, it is possible to create extra budgetary room for a further reduction in payroll taxes, inducing a further increase in formal-sector after-tax income.

It is also important to note that agricultural workers bear a large share of the tax burden in all but the last policy experiment. The model supports policymakers' concerns of a potentially higher incidence of poverty in rural areas resulting from higher energy taxes in developing countries. Agricultural workers, as modeled, do not pay energy or labor taxes, but still bear part of the burden of green tax reform through urban-rural migration effects. Specifically, in the first two policy experiments, a decrease in formal sector employment is partially absorbed by the agricultural sector. This inflow of labor into rural areas pushes down wages in the agricultural sector not only in absolute terms, but also relative to formal sector wages, so that the incidence of poverty as measured by wages is higher. In the third and fourth green tax policies, a higher burden of taxation imposed on informal-sector workers prompts them to escape the brunt of taxation by searching for a formal-sector job or migrating into rural areas. Not all workers are able to find a job in the formal sector, so some of them migrate into rural areas, which again pushes wages down in the agricultural sector.

In the last environmental tax policy, compared with the third and fourth ones, the decline in the income of agricultural workers is moderated. This is because there is a larger reduction in unemployment than before, and as a result fewer people migrate into rural areas.

Green tax policies that put a heavier tax burden on the unemployed, as in the last three policy scenarios, could still be attractive from an efficiency viewpoint, because they improve labor market incentives through increased search effort, $s$. This search effort behavior introduces a wedge between labor market tightness $\theta$ and the vacancy rate $v$ in such a way that these variables move in opposite directions. More specifically, since search intensity is endogenous, labor market tightness depends on two factors: the number of vacancies relative to the number of unemployed workers $(v / u)$, and the average search intensity of the unemployed $(s)$ :

$$
\theta=\frac{v}{u} \frac{1}{S}
$$

In the first two policy experiments, the labor market is less tight because there are more unemployed workers relative to the number of vacancies in the economy, and $\theta$ follows the dynamics of the first channel $v / u$ and falls. In contrast, in the last three policy scenarios, green taxation reduces payroll taxes and raises energy taxes, which imposes a heavier burden on the unemployed by reducing their income from self-employment, $z$. In these cases, the unemployed attempt to evade taxation by more actively seeking a formal-sector job, so that $s$ rises. A higher search intensity makes it easier for employers to fill vacancies, and the labor market tightness, $\theta$, by following the dynamics of search intensity $s$, falls. A less tight labor 
market reduces the expected duration of vacancies $(1 / q(\theta))$ so that the green tax policy of the third and fourth scenarios creates larger incentives to enter the formal sector, inducing labor reallocation from the informal to the formal sector with a higher turnover rate than before.

\subsection{Green Tax Policy Reform and Public Consumption}

As discussed above, by lowering the level of public consumption, it is possible to mitigate the overall tax burden on labor and to increase private-sector after-tax income. In this section, I further discuss the mechanisms and intuition behind this result. I consider different tax reforms, with increases in the energy tax rate ranging from 0.75 percentage points to 25 percentage points from the baseline value of $15 \%$. In each case I start with the baseline tax level, vary the energy tax, and report the resulting steady-state results for the fourth and fifth policy scenarios in Table 5.

There are several key results that emerge from the table. First, labor taxes and unemployment are reduced by more when $G$ varies than when $G$ is fixed. Second, changes in the income of the unemployed from self-employment are almost identical under these two policies. Third, when $G$ varies, formal sector after-tax wages $\left(w_{m}\right)$, agricultural-sector wages $\left(w_{a}\right)$, and unemployment benefits $(b)$ follow a hump-shaped pattern with respect to the changes in energy tax rate: they are initially rising but start falling when the energy tax rate reaches some level higher than the baseline value. Finally, there is a larger reduction in total government revenues under the final policy scenario.

These results can be explained as follows. On the fiscal side, the combination of the payroll tax (albeit lower than in the baseline) and higher carbon taxes reduces total government revenue under both policy scenarios. This is because a reduction in payroll taxes does not outweigh the costs associated with a decrease in energy demand (erosion in the energy tax base), or the costly reduction in labor productivity. Even though labor employment expands, it does not offset the reductions in labor taxes, so that overall tax revenues decline. This reflects the fact discussed earlier that labor taxes are a broader-based tax and thus are a more efficient way of raising revenues than energy taxes. Under the fourth policy experiment, a larger reduction in labor taxes results in even lower tax revenues, despite the higher after-tax wage of workers.

On the expenditure side, there are two components through which these revenue changes are transferred to the rest of the economy: transfers to the unemployed and the provision of public goods. Changes in spending on publicly provided goods, in particular a reduction in public consumption, allows for lower public revenues and thus lower payroll taxes.

If, however, $G$ is fixed, transfers to the unemployed have to be lower, public revenues higher, or a mix of the two. As simulation results (Table 5) demonstrate, it is a combination of the two that occurs: unemployment benefits are lower and total public revenues are higher under the policy when $G$ is fixed compared to when $G$ varies. As mentioned earlier, public revenues are higher because there are smaller reductions in labor taxes. Specifically, a 5\% increase of the energy tax from the baseline value ${ }^{24}$ lowers the payroll tax by $1.45 \%$ when $G$ is fixed compared to $1.75 \%$ when $G$ varies, whilst an increase in the environmental levy of $10 \%$ from the baseline value enables a $2.86 \%$ decrease in labor taxes (compared to $3.47 \%$ ).

The smaller cuts in labor taxes relative to increases in energy taxes under the third policy case is due to the erosion of the carbon tax base. As discussed at the start of Sect. 4.3, to provide a fixed amount of public goods, the government is unable to reduce taxes on labor sufficiently to offset the adverse effect of a higher energy tax on private-sector after-tax

24 From an energy tax of 1 to $15.75 \%$. 


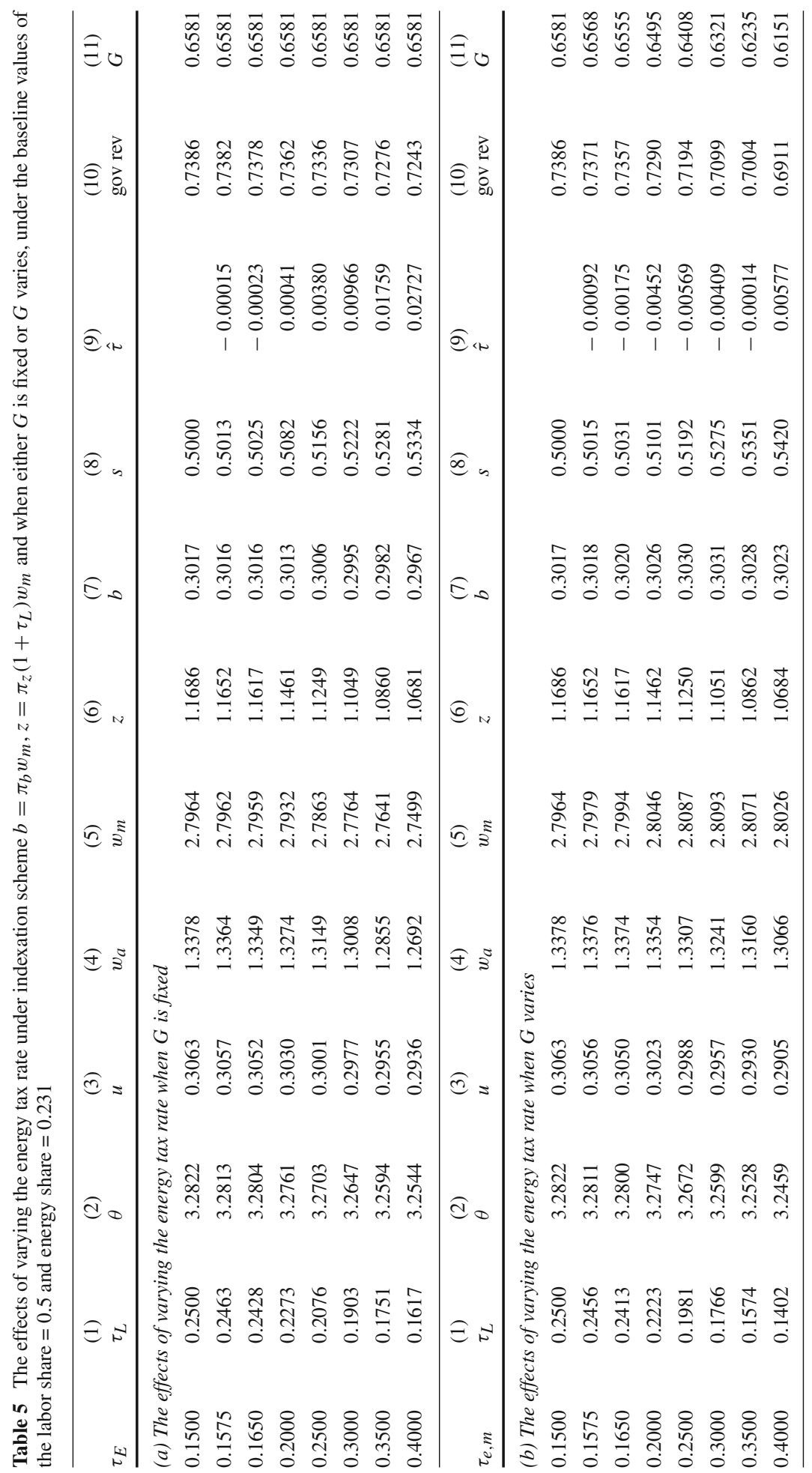


income. Drops in labor taxes are due to the revenue recycling of energy taxes, so to achieve "extra" reductions in marginal taxes on labor, the government needs to resort to additional policy measures. A reduction in public consumption is one of those measures, as a lower level of public spending requires less public revenues, and thus lower payroll taxes. Under the baseline parameterization, the reduction in public consumption results in higher cuts on labor taxes relative to increases in tax on energy, which results in higher real after-tax wages of formal-sector workers, as well as the hump-shaped responses of wages and unemployment benefits (see Table 5).

To explain these results, following Bovenberg and van der Ploeg (1998b) I first define the change in the tax burden on labor resulting from the green tax reform as:

$$
\hat{\tau} \equiv \hat{\tau}_{L}+\frac{\omega_{E}}{\omega_{L}} \hat{\tau}_{e, m}
$$

where changes in taxes are expressed as absolute deviations from their baseline values, and $\omega_{L}=0.5$ and $\omega_{E}=0.231$ stand for shares of labor and energy in formal production respectively. Labor taxes raise wage costs directly, whereas energy taxes indirectly raise wage costs per unit of production by discouraging energy use and reducing labor productivity. Thus, equation (34) states that if the cut in payroll taxes is not sufficient to compensate for these adverse effects of energy taxes, green tax policy raises the overall tax burden, resulting in higher labor costs per unit of output, lower after-tax wages, or both. If a higher tax burden is reflected in higher labor costs, then such a tax policy is likely to discourage the demand for labor and thus reduce employment.

Given the parametrization of the model and these shares of labor and energy in the production process, it is clear that if a reduction in labor taxes exceeds an increase in energy taxes, the tax burden of the green tax reform is likely to be reduced. Specifically, the following condition must hold for the tax burden on real after-tax private income to be lowered:

$$
-\frac{\hat{\tau}_{L}}{\hat{\tau}_{E}}>\frac{\omega_{E}}{\omega_{L}}=0.462
$$

Based on (34), column (9) of Table 5 presents estimates of the changes in the overall tax burden associated with the green tax reform. "Extra" cuts in taxes on labor, stemming from a reduction in public consumption, reduce labor costs per unit of output sufficiently to outweigh energy costs per unit of output associated with a rise in energy tax from its baseline value. If, however, the green tax reform involves a relatively high increase in energy tax, for example 20 percentage points, a reduction in labor taxes is no longer sufficient to offset the adverse effects of energy taxes, and the average tax burden rises in the economy. This suggests that the tax burden follows a J-curve pattern, initially falling before rising.

I argue that this J-curve behavior of the change in the tax burden is conceptually similar to the Laffer curve (the non-monotonic relationship between tax rates and government revenues). Higher environmental taxes induce firms to reduce their demand for energy, eroding the carbon tax base. The erosion in this tax base is particularly high when energy tax rates exceed some higher level, so that a reduction in labor taxes through revenue-recycling and a reduction in public consumption is not sufficient to offset the adverse effects of higher energy taxes on labor productivity and energy demand, and the tax burden starts increasing. As the level of the environmental levy becomes too high (e.g. when $\tau_{e, m}=0.35$ ), the government needs to provide labor subsidies to induce firms to create more vacancies and to increase employment.

This result also implies that a reduction in public expenditure as a complementary policy measure to reduce the tax burden of energy taxes in the economy has limited scope for 
improving outcomes. Reductions in public expenditure can increase the after-tax income of the private sector only up to a certain level of energy taxes, with further reductions in public consumption likely to be counterproductive.

Finally, reductions in public consumption not only translate into lower labor taxes, but also higher transfers to the unemployed. The higher incomes of both unemployed and formalsector workers compared to the third policy case results in a larger urban area and lower rural-urban migration, which results in higher rural-sector income. The only income that remains almost the same under the third and fourth policy scenarios is income generated from informal-sector self-employment. This is because the first-order effects of lower public consumption are on overall tax revenue and unemployment benefits. The effect on income from informal activities is only through the effect on wages $\left(w_{m}\right)$ and labor taxes, which are reduced by more in the last policy experiment; this is almost completely compensated by increases in after-tax wages.

Finally, these results depend critically on the value of the energy intensity of the formal sector production, and thus the values of $\omega_{E}$ and $\omega_{L}$. Specifically, equation (34) also states that the overall effect of changes in both tax rates on the tax burden depends on the share of energy costs relative to labor costs in total production $\left(\omega_{E} / \omega_{L}\right)$. If, for instance, the share of energy is smaller relative to the share of labor, then a given cut in labor taxes lowers the overall tax burden, ceteris paribus. This also implies that a change in the tax burden can be negative (even without these "extra" cuts in tax on labor stemming from lower government expenditure). Column (9) of Table 5 for the case with fixed $G$ illustrates this point: a green tax policy associated with increases of energy tax rate from the baseline value by 0.75 and 1.5 percentage points lowers the tax burden, but a lower tax burden does not translate into higher private-sector after-tax income, which is lower than under the baseline policy. This suggests that a reduction in the tax burden is a necessary but not sufficient condition for private-sector after-tax incomes to be improved through a green tax reform. In the next section, I investigate how this pattern continues with lower values of $\omega_{E} / \omega_{L}$, and the sensitivity of the J-curve behavior of the tax burden to different values of energy intensity.

\section{Welfare Analysis}

Previous analysis revealed that green tax reforms can have positive employment effects and increase the income of both formal and informal workers in the urban sector. However, it was shown that such policies decrease agricultural-sector incomes, under both fixed and endogenous public spending. In this section, I investigate whether a green tax reform is welfare-improving.

So far, the analysis has neglected the effects of changes in public spending on the rest of the economy. It was shown that a green tax reform with endogenous public spending results in a higher employment rate, higher increases in urban-sector incomes, and a lower reduction in agricultural-sector income compared to a tax reform that keeps the level of public spending fixed. Clearly, if other economy-wide effects of a reduction in public spending are taken into consideration, the former tax reform may not actually be superior to the latter. As such, I account for the interaction of public spending with the rest of the economy by assuming that public spending affects households' utility, which for a given value of household income $I$ is defined as follows:

$$
\mathcal{U}(I)=c_{A}^{\alpha_{A}} c_{M}^{\alpha_{M}} G^{\vartheta}
$$


where $\alpha_{A}+\alpha_{M}=1$, subject to the budget constraint: ${ }^{25}$

$$
p_{A} c_{A}+p_{M} c_{M}=I
$$

Households' demand functions are given by the following equations:

$$
c_{A}=\frac{\alpha_{A} I}{p_{A}} ; \quad c_{M}=\frac{\alpha_{M} I}{p_{M}}
$$

A measure of social welfare is defined as the weighted utilities of all agents (formal sector workers, informal, and agricultural):

$$
W=(1-u) L_{m} \mathcal{U}\left(w_{m}+\lambda P\right)+u L_{m} \mathcal{U}(z+b)+L_{a} \mathcal{U}\left(w_{a}\right)
$$

where $\mathcal{U}$ is the households' utility function. The weighted utilities is a valid representation of social welfare and has been used in previous studies. ${ }^{26}$ In addition to this social welfare measure, I compute equivalent variation $(E V)$ for each agent in the economy to see if there are any situations when the urban workers, who experience an increase in incomes, could potentially compensate the rural workers, who face declines in their incomes due to a green tax reform.

I evaluate the welfare costs of two environmental tax reforms that result in a double dividend, which are characterized by indexation scheme Case $\mathrm{C}$, with fixed or endogenous public spending (fourth and fifth tax reforms as in Table 4). These results are demonstrated in Table 6, which presents how welfare and the utilities of each group of agents change for a given increase in the energy tax rate from its baseline value $\tau_{e, m}=0.15$, as well as the equivalent variations of a given tax reform. Table 6 suggests that even though green tax reforms are associated with an increase in all urban-sector incomes, a given environmental tax policy reduces overall social welfare and the utility of each group of workers in the economy. ${ }^{27}$ Furthermore, comparing columns (2)-(4) across tables, we see that for a given level of environmental taxation, $E V$ is lower when public spending varies endogenously compared to when public spending is fixed, even though the former policy is associated with a larger increase in incomes of both formal and informal workers, as discussed in the previous section. As discussed earlier, the larger increase in urban-area incomes is possible due to the reduction in public spending, which creates extra budgetary room. However, as I observe now, such reductions in public spending are not desirable for society in general, since these relatively larger increases in household incomes do not offset the reduction of public consumption, in terms of the well-being of workers.

\footnotetext{
25 Market clearing conditions for agricultural goods and manufacturing goods determine the prices $p_{A}$ and $p_{M}$. Please note that the baseline values at $\tau_{e, m}$ will be different for this version of the model with welfare analysis compared to the baseline values of the model considered earlier, because the model has been modified.

26 For instance, Schneider (1997) uses similar measure of social welfare when he examines the welfare effects of environmental tax reforms. In the macroeconomics literature, a similar weighted sum of per-period utilities is a typical specification of the policy objective, as in Horvath (2009) and Bilbiie (2016).

27 The value of $\vartheta$ is crucial for welfare evaluation. The baseline value of $\vartheta$ is set at 0.1 , while, as discussed earlier, the previous literature suggests higher values of this parameter, 0.2 and 0.4 . As such, I perform sensitivity analysis with respect to a higher values of $\vartheta$. The welfare costs of environmental tax policies depicted in Table 6 will be higher. Intuitively, and as could be expected, with higher values of $\vartheta$ public spending plays more important role for the households' utility and consequently the reduction in public spending will be associated with larger welfare losses.
} 
Table 6 Welfare effects of a green tax reform

\begin{tabular}{lllllllll}
\hline$(1)$ & $(2)$ & $(3)$ & $(4)$ & $(5)$ & $(6)$ & $(7)$ & $(8)$ & $(9)$ \\
$\tau_{e, m}$ & $E V_{a}$ & $E V_{m}$ & $E V_{i}$ & $u$ & $\mathcal{U}_{m}$ & $\mathcal{U}_{i}$ & $\mathcal{U}_{a}$ & $W$ \\
\hline $\begin{array}{l}\text { (a) The welfare effects } \\
\text { when } G \text { is fixed }\end{array}$ & & & & & & & \\
0.1500 & & & 0.3063 & 1.8628 & 0.8385 & 0.7630 & 1.4469 \\
0.1575 & -0.0009 & -0.0022 & -0.0010 & 0.3058 & 1.8624 & 0.8384 & 0.7628 & 1.4466 \\
0.1650 & -0.0009 & -0.0022 & -0.0010 & 0.3053 & 1.8616 & 0.8380 & 0.7625 & 1.4460 \\
0.2000 & -0.0024 & -0.0059 & -0.0026 & 0.3031 & 1.8595 & 0.8370 & 0.7616 & 1.4442 \\
0.2500 & -0.0033 & -0.0081 & -0.0037 & 0.3004 & 1.8582 & 0.8365 & 0.7611 & 1.4421 \\
0.3000 & -0.0031 & -0.0075 & -0.0034 & 0.2981 & 1.8585 & 0.8366 & 0.7612 & 1.4404 \\
0.3500 & -0.0018 & -0.0044 & -0.0020 & 0.2961 & 1.8603 & 0.8374 & 0.7619 & 1.4388 \\
(b) The welfare effects when $G$ varies & & & & & & \\
0.1500 & & & & 0.3055 & 1.8612 & 0.8378 & 0.7624 & 1.4462 \\
0.1575 & -0.0009 & -0.0023 & -0.0010 & 0.3057 & 1.8611 & 0.8378 & 0.7623 & 1.4461 \\
0.1650 & -0.0018 & -0.0045 & -0.0020 & 0.3051 & 1.8595 & 0.8371 & 0.7616 & 1.4453 \\
0.2000 & -0.0055 & -0.0135 & -0.0061 & 0.3023 & 1.8526 & 0.8340 & 0.7588 & 1.4420 \\
0.2500 & -0.0096 & -0.0234 & -0.0105 & 0.2988 & 1.8445 & 0.8303 & 0.7555 & 1.4376 \\
0.3000 & -0.0124 & -0.0303 & -0.0137 & 0.2957 & 1.8381 & 0.8274 & 0.7528 & 1.4337 \\
0.3500 & -0.0142 & -0.0348 & -0.0156 & 0.2930 & 1.8331 & 0.8252 & 0.7508 & 1.4301 \\
\hline
\end{tabular}

The model with $b=\pi_{b} w_{m}, z=\pi_{z}\left(1+\tau_{L}\right) w_{m}$

\section{Sensitivity Analysis}

\subsection{Varying the Energy Intensity of the Formal Sector}

In this section I investigate how the results presented in the previous section would change if I vary the value of the expenditure share of energy in production. The baseline expenditure share of energy is $\omega_{E}=0.231$, which as discussed in Sect. 3, is consistent with some estimates of energy intensity in manufacturing subsectors across developing countries, but is much higher than the values of energy expenditure shares used in recent macroeconomic models of climate change, which have used a value of 0.04 . To accommodate these differences in estimates, I consider values of the expenditure share of energy $\left(1-\alpha_{1}-\alpha_{2} \equiv \omega_{E}\right)$ of between 0.1 and 0.04 , while keeping the value of $\alpha_{1}$, the expenditure share of capital, at its baseline value of 0.269 . I start analyzing the effect of green tax reforms on the economy under three different values of energy share $\omega_{E}$, by focusing on policy scenarios that assume the tax regime $b=\pi_{b} w_{m}, z=\pi_{z}\left(1+\tau_{L}\right) w_{m}$, and $G=\bar{G}$. As before, I consider different tax regimes, with increases in the energy tax rate from its baseline value. In each case I start with the baseline value, vary the energy tax and report the resulting steady-state results for three alternative values of energy share in Table 7. Two key results emerge from the table. First, the J-curve pattern of the change in tax burden associated with implementing green tax reforms can also be observed for revenue-neutral tax reforms and not only for the case when $G=\psi Y$. Second, a reduction in the unemployment rate (the double dividend phenomenon) can be associated with increases in after-tax income of formal workers $\left(w_{m}\right)$ and the unemployed, particularly if the production process is more labor-intensive. Third, for a given rise in energy tax rate, cuts in payroll taxes are lower when production is less energy-intensive. 


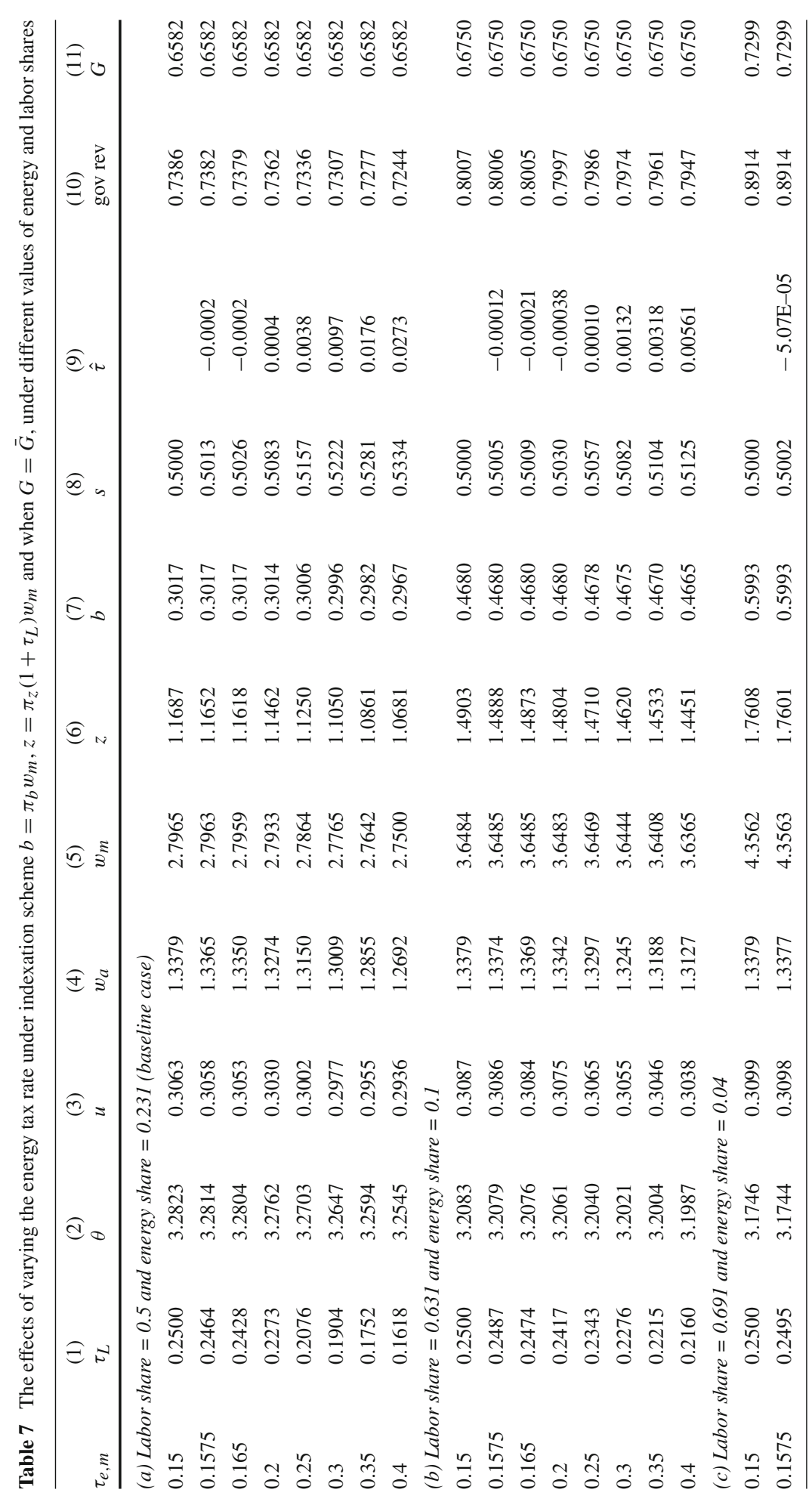




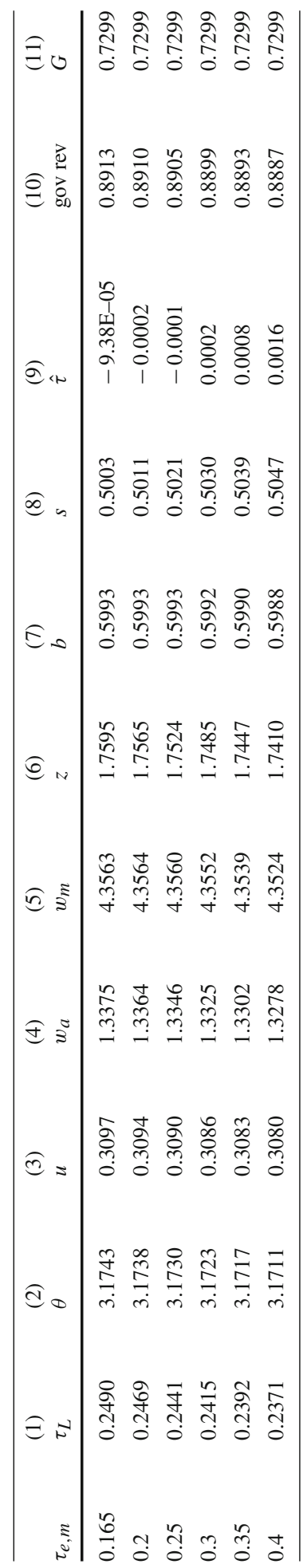

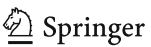


Intuitively, with a smaller share of energy in production, declines in energy demand due to higher energy taxes impose a smaller tax burden. At the same time, there are also fewer energy tax revenues that can be recycled to cut payroll taxes, which have a wider tax base. This suggests that labor taxes can be cut by less when the energy share is smaller. Despite smaller cuts in the labor tax rates, distortions associated with green tax reforms are smaller, so that lower labor taxes can offset reductions in the marginal product of labor due to lower energy demand. In such situations, the after-tax income of formal sector workers and unemployment benefits increases.

The key difference from previous studies that focus on developed countries is that the incidence of carbon taxes in the developing economy studied here is partly shifted to the rural sector through rural-urban migration effects. Thus, even though revenue-neutral green tax policies can be associated with higher after-tax incomes of both the employed in the formal sector and the unemployed, the income of rural workers is lower under all cases considered. This highlights the importance of modeling features relevant for developing countries, since ignoring rural-urban migration effects could potentially make green tax reforms appear Pareto improving, when in fact, the policy trade-off is that the agricultural sector is made worse off in terms of lower wages.

When endogenous changes in public expenditure accompany green tax reforms (under assumption $G=\psi Y$ ), the effect on both the unemployment rate (the double dividend) and private-sector after-tax income is magnified by a further reduction in labor tax rates due to lower public consumption. Similar detailed results are presented in Table 8, and changes in the tax burden are shown in Fig. 1. As Fig. 1 illustrates, a decrease in government spending $G$ leads to a larger decline in the tax burden for a given change in energy tax rate (and a given energy share). I do not report a detailed table with the results under this policy scenario (available upon request), but the patterns and messages are similar as when public consumption is fixed. ${ }^{28}$

\subsection{Worker's Bargaining Power}

As discussed earlier, the potential for a double dividend depends on how environmental taxation affects the income of the unemployed $(z+b)$, and hence the outside option of formalsector workers. Double dividends can arise if environmental regulation changes the outside option of formal-sector workers, so that some of the higher burden of energy taxation can be shifted onto the unemployed. These implications were considered in Case C (proportional unemployment insurance) in Sect. 2.2.5. If, however, environmental policy does not affect the income of the unemployed (for example under fixed unemployment insurance), then the double dividend does not occur.

Aside from the outside option, equilibrium wages of formal sector workers are also influenced by their bargaining power due to the Nash bargaining assumption. As mentioned in Sect. 2.2.4, a higher bargaining power means that formal sector workers can prevent larger cuts in after-tax wages, which raises labor costs and reduces formal sector employment. However, if firms dominate the bargaining process, formal sector wages will be closer to workers' reservation wages (informal sector wages), so labor costs and employment do not respond as much to energy taxation.

These results are demonstrated in Table 9, which presents the simulation results of the effects of environmental regulation on unemployment, for different values of workers' bargaining power: $\beta=0.5$ (baseline), $\beta=0.25$, and $\beta=0.05$. Here, we assume proportional

28 Though with a larger decline in the tax burden, after-tax income of workers increases, whilst rural workers income fall by less. The reduction in the unemployment rate is also larger. 


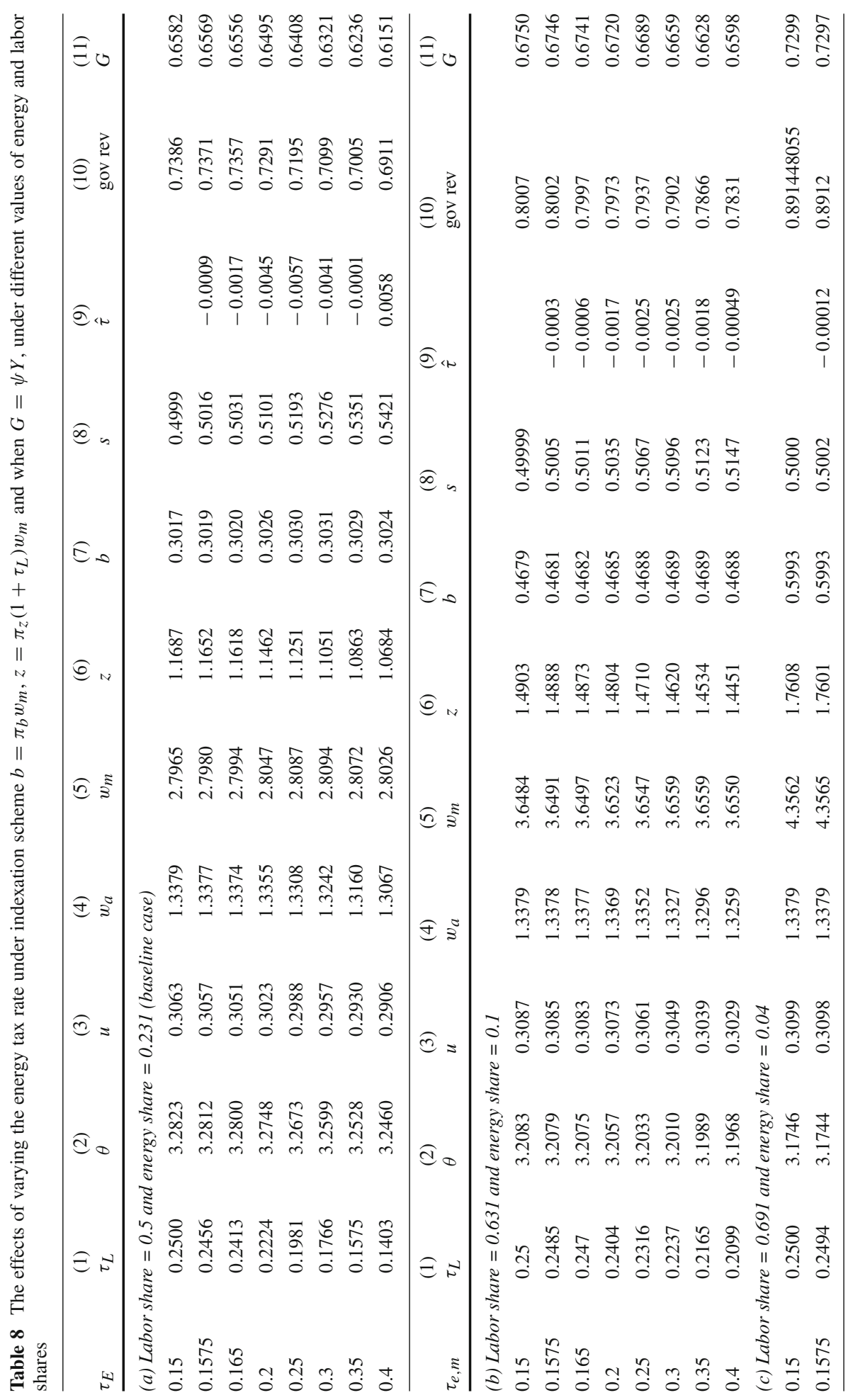




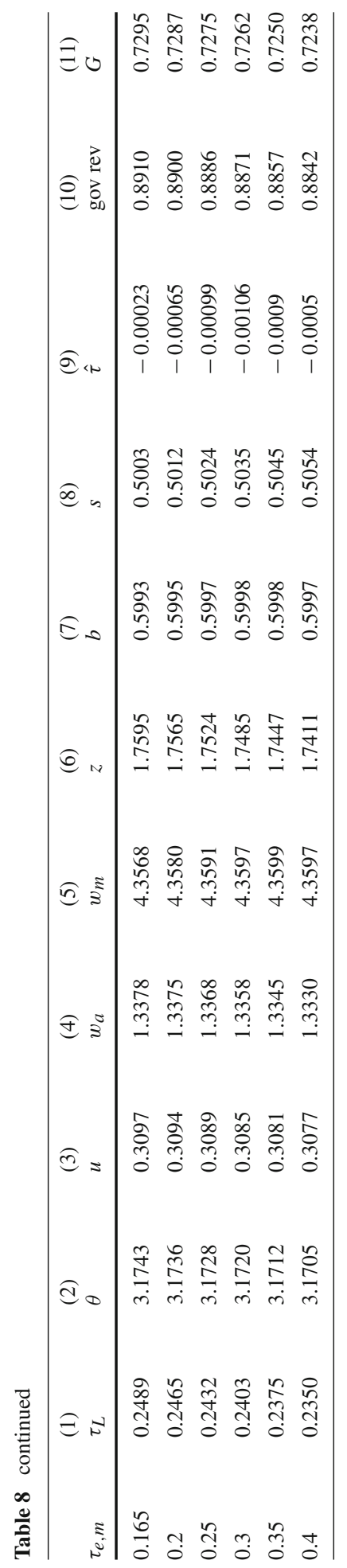




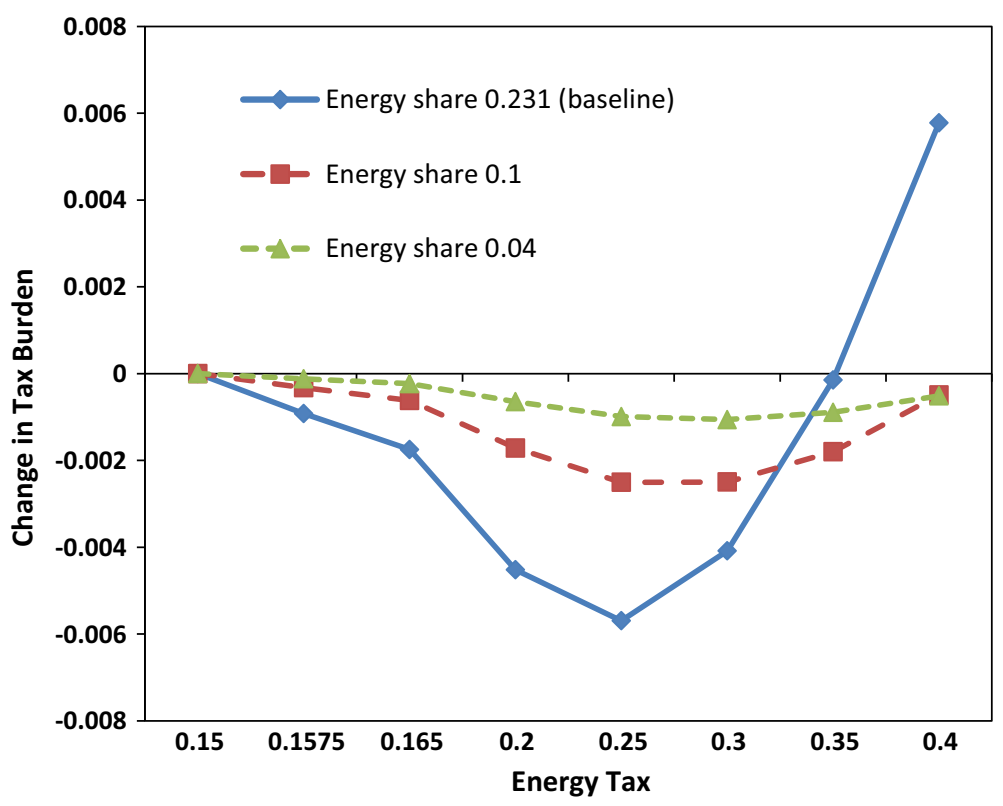

Fig. 1 Change in tax burden for varying values in energy tax rate: different values of energy share, $b=\pi_{b} w_{m}$, $z=\pi_{z}\left(1+\tau_{L}\right) w_{m}, G$ varies

unemployment insurance (UI) in the core model with $\tau_{a}=0.15$, so it is possible to shift the burden of energy taxation onto the unemployed. Table 9 suggests that there is a nonlinear relationship between the unemployment rate $(u)$ and worker's bargaining power $(\beta)$. Comparing columns (2) across tables, we see that for a given level of environmental taxation, unemployment initially falls when bargaining power falls to 0.25 , but then rises when bargaining power decreases further to 0.05 . A similar nonlinear pattern exists for formal-sector wages: comparing columns (4) across tables, we observe that higher bargaining power is initially associated with relatively higher formal sector wages ( $\beta=0.5$ vs $\beta=0.25$ ), but when bargaining power decreases to 0.05 , formal-sector wages become lower in relative terms. Columns (3) and (6) show the informal sector (reservation) wage which, as mentioned earlier, is closer to formal sector wages $w_{m}$ when bargaining power is lower.

\subsection{The Elasticity of Search Costs to Search Intensity}

In the baseline model, the parameter $\phi$ represents the search cost elasticity with respect to search efforts and is set to the value 2 as in Satchi and Temple (2009). The elasticity parameter $\phi$ affects migration decisions through two channels: an increase in search intensity raises search costs as well as the probability of finding a job. If $\phi$ is greater than 1 , then the expected benefits from search, $s \sigma^{\prime}(s)$, exceed the costs, $\sigma(s)$. Based on the equilibrium migration condition (24), workers will therefore prefer to stay in the city rather than migrating to rural areas.

The income of rural workers depends on the degree of urban-rural migration, so by varying the value of $\phi$, we examine how the search cost elasticity affects the distribution of the higher energy tax burden on rural workers. We consider two alternative values: $\phi=1.5$ and $\phi=3$, assuming that energy taxes in the agricultural sector are fixed at the baseline value of 0.15 
Table 9 The effects of varying the energy tax rate under different values of the workers' bargaining power $\beta$. The model with $b=\pi_{b} w_{m}, z=\pi_{z}\left(1+\tau_{L}\right) w_{m}$, varying $G$. Note: unemployment in (2) is normalized with respect to its value at $\tau_{e, m}=0.15$. Column (4) reports formal sector wages relative to the baseline

\begin{tabular}{|c|c|c|c|c|c|c|}
\hline$\tau_{e, m}$ & $\begin{array}{l}(1) \\
\tau_{L}\end{array}$ & $\begin{array}{l}(2) \\
u\end{array}$ & $\begin{array}{l}(3) \\
w_{m}\end{array}$ & $\begin{array}{l}(4) \\
w_{m} \text { normal. }\end{array}$ & $\begin{array}{l}(5) \\
w_{a}\end{array}$ & $\begin{array}{l}\text { (6) } \\
z+b-\sigma\end{array}$ \\
\hline \multicolumn{7}{|c|}{ (a) The effects of varying the energy tax rate when $\beta=0.5$ (baseline) } \\
\hline 0.15 & 0.2500 & 1.0000 & 2.7965 & 1.0000 & 1.3379 & 0.5530 \\
\hline 0.1575 & 0.2456 & 0.9979 & 2.7980 & 1.0005 & 1.3377 & 0.5466 \\
\hline 0.165 & 0.2413 & 0.9959 & 2.7994 & 1.0011 & 1.3374 & 0.5403 \\
\hline 0.2 & 0.2224 & 0.9869 & 2.8047 & 1.0029 & 1.3355 & 0.5122 \\
\hline 0.25 & 0.1981 & 0.9755 & 2.8087 & 1.0044 & 1.3308 & 0.4755 \\
\hline 0.3 & 0.1766 & 0.9655 & 2.8094 & 1.0046 & 1.3242 & 0.4424 \\
\hline 0.35 & 0.1575 & 0.9566 & 2.8072 & 1.0038 & 1.3160 & 0.4124 \\
\hline 0.4 & 0.1403 & 0.9486 & 2.8026 & 1.0022 & 1.3067 & 0.3851 \\
\hline \multicolumn{7}{|c|}{ (b) The effects of varying the energy tax rate when $\beta=0.25$} \\
\hline 0.15 & 0.2500 & 1.0000 & 2.4184 & 1.0000 & 1.3379 & 0.8223 \\
\hline 0.1575 & 0.2457 & 0.9977 & 2.4197 & 1.0005 & 1.3378 & 0.8171 \\
\hline 0.165 & 0.2415 & 0.9954 & 2.4209 & 1.0010 & 1.3376 & 0.8120 \\
\hline 0.2 & 0.2228 & 0.9856 & 2.4251 & 1.0028 & 1.3361 & 0.7893 \\
\hline 0.25 & 0.1989 & 0.9730 & 2.4283 & 1.0041 & 1.3320 & 0.7592 \\
\hline 0.3 & 0.1776 & 0.9620 & 2.4286 & 1.0042 & 1.3259 & 0.7317 \\
\hline 0.35 & 0.1587 & 0.9522 & 2.4265 & 1.0033 & 1.3182 & 0.7065 \\
\hline 0.4 & 0.1417 & 0.9436 & 2.4225 & 1.0017 & 1.3092 & 0.6832 \\
\hline \multicolumn{7}{|c|}{ (c) The effects of varying the energy tax rate when $\beta=0.05$} \\
\hline 0.15 & 0.2500 & 1.0000 & 1.8828 & 1.0000 & 1.3379 & 1.4165 \\
\hline 0.1575 & 0.2458 & 0.9984 & 1.8839 & 1.0006 & 1.3381 & 1.4155 \\
\hline 0.165 & 0.2418 & 0.9969 & 1.8849 & 1.0011 & 1.3382 & 1.4144 \\
\hline 0.2 & 0.2237 & 0.9900 & 1.8887 & 1.0031 & 1.3381 & 1.4090 \\
\hline 0.25 & 0.2006 & 0.9811 & 1.8918 & 1.0048 & 1.3359 & 1.4007 \\
\hline 0.3 & 0.1800 & 0.9733 & 1.8927 & 1.0052 & 1.3319 & 1.3920 \\
\hline 0.35 & 0.1616 & 0.9663 & 1.8916 & 1.0047 & 1.3263 & 1.3828 \\
\hline 0.4 & 0.1451 & 0.9600 & 1.8890 & 1.0033 & 1.3195 & 1.3733 \\
\hline
\end{tabular}

and that the UI scheme is proportional. Table 10 presents the results for different values of $\phi$ and demonstrates that lower values of $\phi$ are associated with a larger urban population and therefore a smaller rural population. The changing value of $\phi$ affects the income of the unemployed $z$ and unemployment benefits $b$, which together with $\sigma\left[\varepsilon_{\sigma}-1\right]$ influence urban-rural migration. Under the given parametrization, with larger returns to urban labour, workers tend to migrate to the city, which increases the income of agricultural workers.

\subsection{Vacancy Posting Costs}

Besides bargaining power and search costs, vacancy posting costs affect formal sector wages and the unemployment rate. Higher vacancy costs means that fewer vacancies are posted, which results in a higher unemployment rate. As discussed in Sect. 2.2.3, the flow cost $c$ 
Table 10 The effects of varying the energy tax rate under different values of the elasticity of search costs with respect to search intensity $\phi$. The model with $b=\pi_{b} w_{m}, z=\pi_{z}\left(1+\tau_{L}\right) w_{m}$, varying $G$

\begin{tabular}{|c|c|c|c|c|}
\hline$\tau_{e, m}$ & $\begin{array}{l}(1) \\
\tau_{L}\end{array}$ & $\begin{array}{l}\text { (2) } \\
u\end{array}$ & $\begin{array}{l}(3) \\
w_{a}\end{array}$ & $\begin{array}{l}\text { (4) } \\
L_{m}\end{array}$ \\
\hline \multicolumn{5}{|c|}{ (a) The effects of varying the energy tax rate when $\phi=1.5$} \\
\hline 0.15 & 0.2500 & 1.0000 & 1.3379 & 0.8700 \\
\hline 0.1575 & 0.2455 & 0.9964 & 1.3382 & 0.8700 \\
\hline 0.165 & 0.2411 & 0.9929 & 1.3384 & 0.8701 \\
\hline 0.2 & 0.2218 & 0.9776 & 1.3387 & 0.8701 \\
\hline 0.25 & 0.1970 & 0.9584 & 1.3371 & 0.8699 \\
\hline 0.3 & 0.1751 & 0.9417 & 1.3333 & 0.8693 \\
\hline 0.35 & 0.1556 & 0.9270 & 1.3279 & 0.8684 \\
\hline 0.4 & 0.1382 & 0.9141 & 1.3210 & 0.8674 \\
\hline
\end{tabular}

(b) The effects of varying the energy tax rate when $\phi=2$ (baseline)

$\begin{array}{lllll}0.15 & 0.2500 & 1.0000 & 1.3379 & 0.8700 \\ 0.1575 & 0.2456 & 0.9979 & 1.3377 & 0.8700 \\ 0.165 & 0.2413 & 0.9959 & 1.3374 & 0.8699 \\ 0.2 & 0.2224 & 0.9869 & 1.3355 & 0.8696 \\ 0.25 & 0.1981 & 0.9755 & 1.3308 & 0.8689 \\ 0.3 & 0.1766 & 0.9655 & 1.3242 & 0.8679 \\ 0.35 & 0.1575 & 0.9566 & 1.3160 & 0.8666 \\ 0.4 & 0.1403 & 0.9486 & 1.3067 & 0.8650\end{array}$

(c) The effects of varying the energy tax rate when $\phi=3$

\begin{tabular}{lllll}
0.15 & 0.2500 & 1.0000 & 1.3379 & 0.8700 \\
0.1575 & 0.2456 & 0.9985 & 1.3371 & 0.8699 \\
0.165 & 0.2414 & 0.9970 & 1.3362 & 0.8697 \\
0.2 & 0.2226 & 0.9904 & 1.3316 & 0.8690 \\
0.25 & 0.1984 & 0.9820 & 1.3233 & 0.8677 \\
0.3 & 0.1771 & 0.9747 & 1.3132 & 0.8661 \\
0.35 & 0.1581 & 0.9681 & 1.3019 & 0.8642 \\
0.4 & 0.1410 & 0.9622 & 1.2895 & 0.8622 \\
\hline
\end{tabular}

to post a vacancy depends on hiring costs $v$, payroll taxes $\tau_{L}$, and formal sector wages $w_{m}$ : $c=v\left(1+\tau_{L}\right) w_{m}$.

Table 11 presents the simulation results of the effects of environmental regulation on unemployment, for different vacancy posting costs: $v=0.4$ (baseline), $v=0.2$, and $v=0.6$. For a given value of $v$, an increase in environmental taxation results in more vacancies being posted (and a lower unemployment rate) because the fall in payroll taxes (column (1)) more than offset the increase in wages (column (3)). However, comparing columns (2) across tables shows that for a given level of environmental taxation, the direct increase in flow costs due to an increase in $v$ leads to relatively higher unemployment, even though there are relatively more vacancies, as the search intensity of workers is lower (not shown in the table).

\subsection{A Nested CES Production Function}

The baseline model assumes an open capital account and a Cobb-Douglas specification of production function, which is consistent with this assumption. Some developing countries, 
Table 11 The effects of varying the energy tax rate under different values of vacancy posting costs, $v$
The model with $b=\pi_{b} w_{m}$, $z=\pi_{z}\left(1+\tau_{L}\right) w_{m}$, varying $G$. Note: the number of vacancies in (7) is normalized with respect to its value at $\tau_{e, m}=0.15$

\begin{tabular}{lllllll}
\hline & $(1)$ & $(2)$ & $(3)$ & $(4)$ & $(5)$ & $(6)$ \\
$\tau_{e, m}$ & $\tau_{L}$ & $u$ & $w_{m}$ & $w_{a}$ & $L_{m}$ & $v$ \\
\hline
\end{tabular}

(a) The effects of varying the energy tax rate when $v=0.2$

$\begin{array}{lllllll}0.15 & 0.2500 & 1.0000 & 2.9720 & 1.3379 & 0.8700 & 1.0000 \\ 0.1575 & 0.2456 & 0.9977 & 2.9736 & 1.3378 & 0.8700 & 1.0005 \\ 0.165 & 0.2413 & 0.9954 & 2.9752 & 1.3376 & 0.8700 & 1.0011 \\ 0.2 & 0.2222 & 0.9853 & 2.9810 & 1.3359 & 0.8697 & 1.0034 \\ 0.25 & 0.1977 & 0.9726 & 2.9855 & 1.3311 & 0.8690 & 1.0061 \\ 0.3 & 0.1761 & 0.9614 & 2.9864 & 1.3240 & 0.8678 & 1.0084 \\ 0.35 & 0.1568 & 0.9515 & 2.9842 & 1.3150 & 0.8664 & 1.0103 \\ 0.4 & 0.1396 & 0.9427 & 2.9795 & 1.3044 & 0.8647 & 1.0119\end{array}$

(b) The effects of varying the energy tax rate when $v=0.4$ (baseline)

$\begin{array}{lllllll}0.15 & 0.2500 & 1.0000 & 2.7965 & 1.3379 & 0.8700 & 1.0000 \\ 0.1575 & 0.2456 & 0.9979 & 2.7980 & 1.3377 & 0.8700 & 1.0007 \\ 0.165 & 0.2413 & 0.9959 & 2.7994 & 1.3374 & 0.8699 & 1.0015 \\ 0.2 & 0.2224 & 0.9869 & 2.8047 & 1.3355 & 0.8696 & 1.0046 \\ 0.25 & 0.1981 & 0.9755 & 2.8087 & 1.3308 & 0.8689 & 1.0085 \\ 0.3 & 0.1766 & 0.9655 & 2.8094 & 1.3242 & 0.8679 & 1.0118 \\ 0.35 & 0.1575 & 0.9566 & 2.8072 & 1.3160 & 0.8666 & 1.0146 \\ 0.4 & 0.1403 & 0.9486 & 2.8026 & 1.3067 & 0.8650 & 1.0170\end{array}$

(c) The effects of varying the energy tax rate when $v=0.6$

\begin{tabular}{lllllll}
0.15 & 0.2500 & 1.0000 & 2.6850 & 1.3379 & 0.8700 & 1.0000 \\
0.1575 & 0.2456 & 0.9981 & 2.6864 & 1.3376 & 0.8700 & 1.0009 \\
0.165 & 0.2414 & 0.9962 & 2.6877 & 1.3373 & 0.8699 & 1.0017 \\
0.2 & 0.2225 & 0.9881 & 2.6927 & 1.3353 & 0.8696 & 1.0054 \\
0.25 & 0.1983 & 0.9776 & 2.6965 & 1.3307 & 0.8689 & 1.0100 \\
0.3 & 0.1769 & 0.9684 & 2.6970 & 1.3245 & 0.8679 & 1.0140 \\
0.35 & 0.1579 & 0.9602 & 2.6948 & 1.3170 & 0.8667 & 1.0174 \\
0.4 & 0.1407 & 0.9528 & 2.6903 & 1.3084 & 0.8653 & 1.0204 \\
\hline
\end{tabular}

however, are more integrated with financial markets than the others. In this section I investigate how the baseline results change for such countries, by focusing on a CES representation of energy demand. Specifically, I repeat the simulations of all four policy experiments when the production function in the formal sector is assumed to be a nested CES production function as in (31). I discuss the main conclusions below.

In all policy experiments, the effects on variables are less pronounced, because with a lower elasticity of substitution between labor and energy, imposing a carbon tax has a small impact on the relative cost of labor, and consequently on labor demand and labor market outcomes. Another key result for the case with a nested CES function is that the hump-shaped pattern of some variables under Case $C\left(b=\pi_{b} w_{m} ; z=\pi_{z}\left(1+\tau_{L}\right) w_{m}\right)$ and varying public consumption (Table 12) disappears. ${ }^{29}$ The low elasticity of substitution between labor and energy, along with the imposition of energy taxes, do not allow the overall tax burden to fall (for example, a 5\% increase in energy taxes lowers pay-

29 Simulation results of the first and third policy experiments with a nested CES production function are available upon request. 
Table 12 Effects of varying the energy tax rate: CES production function, $G$ varies, $b=\pi_{b} w_{m}, z=$ $\pi_{z}\left(1+\tau_{L}\right) w_{m}$, baseline labor share $=0.5$ and energy share $=0.231$

\begin{tabular}{llllllllllll}
\hline Taxes & \multicolumn{10}{c}{ व } \\
\hline$\tau_{e, m}$ & $\tau_{L}$ & $\theta$ & $u$ & $w_{m} / w_{a}$ & $w_{m}$ & $z$ & $b$ & $s$ & $v$ & $G$ \\
\hline 0.1500 & 0.2500 & 3.5448 & 0.2981 & 1.7837 & 2.3864 & 1.0771 & 0.0856 & 0.4999 & 0.5285 & 0.5906 \\
0.1575 & 0.2487 & 3.5446 & 0.2980 & 1.7847 & 2.3852 & 1.0755 & 0.0855 & 0.5004 & 0.5286 & 0.5907 \\
0.1650 & 0.2475 & 3.5443 & 0.2978 & 1.7856 & 2.3842 & 1.0739 & 0.0855 & 0.5009 & 0.5287 & 0.5909 \\
0.2000 & 0.2417 & 3.5429 & 0.2969 & 1.7900 & 2.3786 & 1.0665 & 0.0853 & 0.5030 & 0.5293 & 0.5917 \\
0.2500 & 0.2334 & 3.5408 & 0.2957 & 1.7960 & 2.3714 & 1.0562 & 0.0850 & 0.5061 & 0.5300 & 0.5929 \\
0.3000 & 0.2251 & 3.5386 & 0.2945 & 1.8019 & 2.3646 & 1.0460 & 0.0848 & 0.5092 & 0.5308 & 0.5939 \\
0.3500 & 0.2167 & 3.5363 & 0.2933 & 1.8078 & 2.3582 & 1.0360 & 0.0846 & 0.5124 & 0.5315 & 0.5951 \\
0.4000 & 0.2083 & 3.5339 & 0.2921 & 1.8136 & 2.3520 & 1.2969 & 0.0844 & 0.5156 & 0.5323 & 0.5962 \\
\hline
\end{tabular}

roll taxes by a tiny $0.48 \%$, compared with $1.75 \%$ in the baseline policy scenario with a Case $\mathrm{C}$ tax regime and varying public consumption), so the hump-shaped pattern disappears.

The results point out that it is harder to reduce emissions with a lower elasticity, because of a smaller decline in demand for energy. At the same time, the results also imply that green tax policies under a lower elasticity are associated with higher public revenues and consequently with higher general public spending, as the last column of Table 12 illustrates. The results are consistent with other studies that point out the importance of the elasticity of substitution between energy and labor (capital) for the effectiveness of emission reduction initiatives. $^{30}$

\section{Conclusion}

In this paper I study the employment and welfare implications of environmental tax reforms, which are accompanied by three alternative assumptions about public spending: (1) as part of a revenue-neutral policy, (2) fixed, and (3) varying endogenously. The results demonstrate that, under a taxation scheme that gives rise to a double dividend, a lower level of public spending is associated with a smaller negative impact on the after-tax income of all households and a higher increase in employment, and the lowest level of public spending occurs when it varies endogenously as a fraction of GDP. These green reforms, however, still lead to a reduction in social welfare, and even more so in the case of endogenous public spending. As such, lower public spending as a complementary policy to improve the labor market effects of environmental tax reforms in developing countries are likely to be unsuccessful. Policymakers should therefore look for other alternative and more socially acceptable ways to reduce the tax burden on

\footnotetext{
${ }^{30}$ For example, Jorgenson et al. (2000), using a computable general equilibrium model for the US economy, IGEM, find that rigidity in production (in a form of inability to substitute labor, capital, or other materials for energy) more than doubles the costs of mitigation policies. The varying values of elasticity of substitution between energy and labor (capital) can also affect the effectiveness of mitigation policies, with high inter-factor (between energy and value-added) and inter-fuel substitution elasticities generating large carbon leakages.
} 
labor to support the implementation of environmental tax reforms in developing countries.

Open Access This article is distributed under the terms of the Creative Commons Attribution 4.0 International License (http://creativecommons.org/licenses/by/4.0/), which permits unrestricted use, distribution, and reproduction in any medium, provided you give appropriate credit to the original author(s) and the source, provide a link to the Creative Commons license, and indicate if changes were made.

\section{References}

Albrecht J, Navarro L, Vroman S (2009) The effects of labour market policies in an economy with an informal sector. Econ J 119(539):1105-1129

Barrage L (2012) Optimal dynamic carbon taxes in a climate-economy model with distortionary fiscal policy. Mimeo, Yale University, New York

Bento A, Jacobsen M, Liu AA (2012) Environmental policy in the presence of an informal sector. Mimeo, New York

Bilbiie F (2016) Limited asset market participation, monetary policy and (inverted) aggregate demand logic. J Econ Theory 140(1):162-196

Binmore K, Rubinstein A, Wolinsky A (1986) The Nash bargaining solution in economic modelling. RAND J Econ 17(2):176-188

Bosch M, Campos-Vazquez RM (2010) The trade-offs of social assistance programs in the labor market: the case of the Seguro Popular program in Mexico. Serie documentos de trabajo del Centro de Estudios Econmicos 2010-2012. El Colegio de Mxico, Centro de Estudios Econmicos

Bovenberg A, van der Ploeg F (1994) Effects of the tax and benefit system on wage formation and unemployment. mimeo, University of Tilburg

Bovenberg L (1995) Environmental taxation and employment. De Econom 143:111-140

Bovenberg L (1999) Green tax reforms and the double dividend: an updated reader's guide. Int Tax Public Finance 6:421-443

Bovenberg L, van der Ploeg F (1998) Consequences of environmental tax reform for unemployment and welfare. Environ Resour Econ 12:137-150

Bovenberg L, van der Ploeg F (1998) Tax reform, structural unemployment and the environment. Scand J Econ 100(3):593-610

Dissou Y, Karnizova L, Sun Q (2012) Industry-level econometric estimates of energy-capital-labor substitution with a nested CES production function. Working paper n1214E, Department of Economics, University of Ottawa

Ganelli G, Tervala J (2007) Public infrastructures, public consumption, and welfare in a new-open-economymacro model. IMF working paper, $07 / 67$

Gerard F, Gonzaga G (2012) Social insurance and imperfect monitoring. Working paper, Columbia University

Gollin D, Lagakos D, Waugh ME (2014) The agricultural productivity gap in developing countries. Q J Econ 129(2):939-993

Golosov M, Hassler J, Krusell P, Tsyvinski A (2014) Optimal taxes on fossil fuel in general equilibrium. Econometrica 82(1):41-88

Gong X, van Soest A (2002) Wage differentials and mobility in the urban labour market: a panel data analysis for Mexico. Labour Econ 9(4):513-529

Handbook (2012) Mexico Company Laws and Regulations Handbook. International Business Publications

Harris JR, Todaro MP (1970) Migration, unemployment and development: a two-sector analysis. Am Econ Rev 60(1):126-142

Hassler J, Krusell P, Olovsson C (2012) Energy-saving technical change. NBER working paper 18456

Hijzen A (2011) The labour market effects of unemployment compensation in Brazil. OECD social, employment and migration working papers 119. OECD Publishing

Horvath M (2009) The effects of government spending shocks on consumption under optimal stabilization. Eur Econ Rev 53:815-829

ILO (2012) Statistical update on employment in the informal economy. ILO-Department of Statistics. http:// laborsta.ilo.org/informal_economy_E.html

Jorgenson D, Goettle RJ, Willcoxen PJ, Ho MS (2000) The role of substitution in understanding the costs of climate change policy. Report for the Pew Center on Global Climate Change 
Keen M (2008) VAT, tarifs, and withholding: border taxes and informality in developing countries. J Public Econ 92:1892-1906

Koskela E, Schob R (1999) Alleviating unemployment: the case for green tax reforms. Eur Econ Rev 43:17231746

Kuralbayeva K Unemployment, rural-urban migration and environmental regulation. Rev Dev Econ. https:// doi.org/10.1111/rode. 12360

Liu AA (2013) Tax evasion and optimal environmental taxes. J Environ Econ Manag 66:656-670

Mortensen DT, Pissarides CA (1994) Job creation and job destruction in the theory of unemployment. Rev Econ Stud 61(3):397-415

Pigott J, Whalley J (2001) VAT base broadening, self supply, and the informal sector. Am Econ Rev 91(4):10841094

Pissarides C (1998) The impact of employment tax cuts on unemployment and wages; the role of unemployment benefits and tax structure. Eur Econ Rev 42(1):155-183

Pissarides C (2000) Equilibrium unemployment theory, vol 1, 2nd edn. MIT Press, Cambridge

Rogerson R, Shimer R, Wright R (2005) Search-theoretic models of the labor market: a survey. J Econ Lit XLIII:959-988

Satchi M, Temple J (2009) Labor markets and productivity in developing countries. Rev Econ Dyn 12(1):183204

Schneider K (1997) Involuntary unemployment and environmental policy: the double dividend hypothesis. Scand J Econ 99(1):45-59

Sims E, Wolff J (2014) The output and welfare effects of government spending shocks over the business cycle. University of Notre Dame

Upadhyaya S (2010) Compilation of energy statistics for economic analysis. Working paper 01/2010

Velasquez M (2010) Seguros de desempleo y reformas recientes en America Latina, CEPAL - Serie Macroeconoma del desarrollo 99, Naciones Unidas

Vodopivec M (2013) Introducing unemployment insurance to developing countries. IZA J Labor Policy 2(1):123

Yuan C, Liu S, Junlong W (2009) Research on energy-saving effect of technological progress based on CobbDouglas production function. Energy Policy 37(8):2842-2846

Zenou Y (2008) Job search and mobility in developing countries. Theory and policy implications. J Dev Econ $86(2): 336-355$ 